NBER WORKING PAPER SERIES

\title{
THE CLIMATE FOR BUSINESS DEVELOPMENT AND EMPLOYMENT GROWTH IN PUERTO RICO
}

\author{
Steven J. Davis \\ Luis Rivera-Batiz \\ Working Paper 11679 \\ http://www.nber.org/papers/w11679 \\ NATIONAL BUREAU OF ECONOMIC RESEARCH \\ 1050 Massachusetts Avenue \\ Cambridge, MA 02138 \\ September 2005
}

This paper was prepared for a conference on the Puerto Rican economy sponsored by the Center for the New Economy, San Juan, Puerto Rico, and the Brookings Institution. We thank Marinés Aponte, David Audretsch, Barry Bosworth, Susan Collins, colleagues at the University of Chicago and participants in the $\mathrm{CNE}$ /Brookings Conference for many helpful comments. We also greatly appreciate the many persons who cooperated in interviews, often lengthy, about the Puerto Rican business climate. Barry Bosworth and Orlando Sotomayor kindly supplied data, Sophie Castro-Davis and Christopher Pope provided research assistance, Juan Castañer clarified aspects of the methodology in Estudios Técnicos (2004), and Ricardo Solá supplied Figure 4 in the paper. The views expressed herein are those of the author(s) and do not necessarily reflect the views of the National Bureau of Economic Research.

(C2005 by Steven J. Davis and Luis Rivera-Batiz. All rights reserved. Short sections of text, not to exceed two paragraphs, may be quoted without explicit permission provided that full credit, including (C) notice, is given to the source. 
The Climate for Business Development and Employment Growth in Puerto Rico

Steven J. Davis and Luis Rivera-Batiz

NBER Working Paper No. 11679

September 2005

JEL No. J21, J23, D73, O54

\section{ABSTRACT}

Employment rates in Puerto Rico range from 55 to 65 percent of U.S. rates during the past thirty years. This huge employment shortfall holds for men and women, cuts across all education groups, and is deeper for persons without a college degree. The shortfall is concentrated in the private sector, especially labor-intensive industries that rely heavily on less educated workers. Motivated by these facts, we identify several factors that undermine employment growth and business development, including high minimum wage requirements, a history of tax incentives for capital-intensive activities, a host of regulatory entry barriers, and a business climate in which profitability and survival too often rest on the ability to secure favors from the government,. We pay close attention to the permitting process whereby the government oversees and regulates construction and real estate development projects, the commercial use of equipment and facilities, and the periodic renewal of various business licenses. Based on interviews with experts and participants in the permitting process, and supplemented by other sources, we compile evidence that the permitting process is excessively slow and costly, fraught with uncertainty, subject to capricious outcomes, susceptible to corruption, and prone to manipulation by business rivals and special interest groups.

Steven J. Davis

University of Chicago

Graduate School of Business

5807 South Woodlawn Avenue

Chicago, IL 60637

and NBER

steve.davis@gsb.uchicago.edu
Luis Rivera-Batiz

University of Puerto Rico

Graduate School of Business Administration

Rio Pedras, PR 00931

lariverabatiz@aol.com 


\section{Introduction}

The employment rate among Puerto Rican residents is stunningly low, and it has been so for decades. Household census data for 1980, 1990 and 2000 yield employment rates in the neighborhood of $40 \%$ for persons 16 to 65 years of age. Comparable data for the United States yield employment rates in the range of 65 to 70\%. The OECD reports an average employment rate of $66 \%$ for member countries in 2000 , and Turkey, at $49 \%$, is the only OECD member with an employment rate below 54\%. ${ }^{1}$ These comparisons underscore the puzzle presented by Puerto Rico's persistently low employment rate.

This paper investigates the employment record in Puerto Rico and its climate for business development. The paper has three related goals. One is to shed new light on the reasons for Puerto Rico's low employment rate by taking a close look at its employment structure. Another is to highlight some longer term consequences of Puerto Rico's business climate and chronically weak employment performance. A third goal is to identify government policies and institutional arrangements that impede employment growth and business development.

In terms of our third goal, we pay close attention to the permitting process whereby the government oversees and regulates construction and real estate development projects, the commercial use of equipment and facilities, and the periodic renewal of various business licenses. Several factors contribute to Puerto Rico's poor employment performance, but there are good reasons to suspect that the permitting process is one important obstacle to business development and employment growth. Anecdotal evidence suggests that the permitting process is excessively slow and costly, fraught with uncertainty, subject to capricious outcomes, susceptible to corruption, and prone to manipulation by business rivals, politicians and special interest groups. Problems and inefficiencies in the permitting process raise the costs of creating new business establishments, undercutting the drive for employment growth. Sizable fixed costs in learning how to navigate the system fall more heavily on smaller and younger businesses

\footnotetext{
${ }^{1}$ The OECD statistics are taken from Table B in the Statistical Annex to the 2004 issue of the $O E C D$ Employment Outlook. The statistics for Puerto Rico and the United States reflect our tabulations of household census data. It is worth remarking that the OECD figure for the 2000 U.S. employment rate is five percentage points higher than our census-based figure, implying that the two data sources are not fully compatible. There are also concerns about the accuracy of the Puerto Rican household census data, as we discuss below. However, there is little doubt regarding the central point that Puerto Rico has a remarkably low rate of employment.
} 
and on would-be entrepreneurs who lack political connections. For these reasons, the permitting process is also likely to repress the emergence of a productive entrepreneurial culture, or drive it into the underground sector.

The permitting process is one aspect of an obtrusive and often counterproductive role for government in Puerto Rico's economy. There are many others. Section 936 provisions in the U.S. tax code distorted Puerto Rico's industry structure at great cost to the U.S. treasury with few benefits for Puerto Rican residents (Pelzman, 2002, Hunter, 2003, and Bosworth and Collins, 2005). Puerto Rico's own tax code is replete with provisions that benefit special business interests at the expense of the general welfare. Various "buy local" laws and tax provisions lessen competitive pressures on local business interests by disfavoring foreign producers. Regulatory entry barriers abound. The Jones Act raises the cost of international trade by requiring the use of American vessels for goods shipped by water between U.S. and Puerto Rican ports. Puerto Rican employers are subject to U.S. minimum wage requirements, even though the average Puerto Rican wage is roughly half the average U.S. wage. Government transfer payments account for more than a quarter of Puerto Rican household incomes in recent decades (Burtless and Sotomayor, 2005). And the Puerto Rican government has traditionally accounted for a large share of employment and production activity on the island, much larger than in the United States.

A truly striking feature of Puerto Rico's economy is the underdeveloped state of its private sector. Private sector employment rates in Puerto Rico are less than half the U.S. rates in recent decades. Even fewer Puerto Rican residents have first-hand experience, as owners or employees, in "free enterprise" organizations - private businesses that operate in the formal economy without large government subsidies, special tax breaks and regulatory advantages, or heavy-handed oversight by government bureaucracies.

These observations about Puerto Rico's economy point to some key challenges and concerns. First, chronically low employment rates imply that Puerto Rican residents 
are short on work experience, opportunities for learning on the job and marketable skills. ${ }^{2}$ Second, the management skills and business savvy required for a thriving entrepreneurial class are likely to be in especially short supply. Relatively few Puerto Ricans work in the private sector, and business persons have learned to focus their creative energies on how to curry favor with government officials and circumvent bureaucratic obstacles to commercial success, rather than how to develop and execute business models that can withstand the rigors of competition in an unfettered marketplace. Even if reform creates an institutional framework that is advantageous for productive entrepreneurial activity and long term growth, it will be difficult to rapidly upgrade business skills and reorient a rent-seeking business culture. Third, most Puerto Ricans have a strong financial stake in maintaining certain aspects of an expansive public sector - as salaried government employees, as recipients of transfer payments and public sector pensions, or as beneficiaries of government contract awards, subsidies, tax breaks and special regulatory advantages. This web of vested interests in a highly socialized economy presents a formidable barrier to effective economic reform.

The paper proceeds as follows. Section 2 investigates the structure of employment in Puerto Rico with a focus on comparisons to the United States. Section 3 considers several policies and institutions that shape the climate for business development and employment growth in Puerto Rico. Section 4 considers the permitting process in some detail. We draw on a variety of sources for our study of the permitting process, including personal interviews with more than one hundred business persons, real estate developers, construction contractors, government officials and outside experts. Section 5 summarizes our main results and distills a few conclusions.

\section{A Comparative Perspective on Employment in Puerto Rico}

\subsection{Private, Public and Free Enterprise Employment Rates}

There is an enormous gap between employment rates in Puerto Rico and the United States. As reported in Table 1, only $37.5 \%$ of Puerto Rican residents (16-65 years old) held a job during the reference week of the 2000 household census, compared to $68.8 \%$

\footnotetext{
${ }^{2}$ The importance of work experience and on-the-job training for skill formation and earnings growth are recurring themes in modern labor economics. See, Mincer (1962) and Becker (1993, chapter 2) for seminal contributions.
} 
for the United States. Census data also show an enormous employment gap in 1980 and 1990. Figure 1 draws on perennial labor force surveys rather than the decennial household census to plot employment rates from 1947 to 2001. The labor force survey presents a less dire picture in recent years than the 2000 census, but it confirms that Puerto Rico's employment rate is remarkably low in recent decades. ${ }^{3}$

Figure 1 reveals several other interesting facts. Puerto Rico's employment situation was much stronger at the midpoint of the $20^{\text {th }}$ century, with an employment shortfall relative to the United States of less than seven percentage points. U.S. employment rates drifted upward over the next five decades, but they fell sharply in Puerto Rico - by 7 percentage points in the 1950s, and by another 10 percentage points from 1973 to 1982 before recovering some lost ground. Figure 1 also shows that the U.S.-Puerto Rican employment gap widened greatly for both sexes after the early 1950s, from 5 to 25 percentage points among women and from 10 to 20 percentage points among men.

These data indicate that, since 1975, Puerto Rican residents have been accumulating work experience at only 55-65\% of the rate in the United States. This huge experience deficit is a negative legacy of Puerto Rico's chronically weak employment performance, and it cannot be erased over night. ${ }^{4}$ It will depress the earnings potential of Puerto Ricans for years to come. By the same token, strong and sustained increases in the employmentpopulation ratio are essential for long term development of Puerto Rico's human capital.

The U.S.-Puerto Rican gap in private sector employment rates is even more extreme. According to Census data, only 28 percent of Puerto Rican adults worked in the private sector in 2000, less than half the 58 percent figure for the mainland. A similar pattern prevails in 1980 and 1990. These private sector employment figures overstate first-hand exposure to employment in the unfettered "free enterprise" segment of the formal

\footnotetext{
${ }^{3}$ Bosworth and Collins (2005) raise questions about the reliability of the Puerto Rican household census, especially the 2000 census. Based on comparisons to the labor force survey and payroll records, Bosworth and Collins conclude that the 2000 census seriously understates the participation rate (and presumably the employment rate). Their Table 6 shows that the participation rate in the 2000 census is about five percentage points below the rate in the labor force survey. The accuracy of the Puerto Rican labor force survey has also been called into question. See Rivera-Batiz and Santiago (1996). In any event, all sources show a huge U.S.-Puerto Rican gap in employment rates. We rely heavily on the household census for our study, because several of our empirical exercises require large samples of individual workers.

${ }^{4}$ A careful effort to quantify the experience deficit among Puerto Rican residents would account for work experience accumulated on the mainland by return migrants and any U.S.-Puerto Rican difference in average hours worked by employed persons. We address the latter issue shortly.
} 
economy. Indeed, many Puerto Ricans with private sector jobs work in industries with a major role for government employment (e.g., hospitals, schools), industries that owe their Puerto Rican operations to special tax subsidies (e.g., pharmaceuticals), or industries that face costly bureaucratic obstacles to business activity (e.g., construction). Similar remarks apply to many private sector jobs in the United States, but the government's role is typically more extensive on the island, as shown by some of our evidence below.

Table 1 reports the fraction of Puerto Rican adults who work in the free enterprise segment of the economy, defined as private sector employment less non-governmental employees in Public Utilities and Sanitary Services, Primary and Secondary Education, Colleges and Universities, and several smaller industries for which public sector employment exceeds $35 \%$ of industry employment. ${ }^{5}$ We also exclude Construction from the free enterprise segment because of the major role played by the government bureaucracy in construction and development projects, an issue treated at length in Section 4. We do not exclude Pharmaceuticals or other industries that receive large government subsidies or special tax breaks, although the Puerto Rican operations of such industries do not reflect unfettered free enterprise outcomes. Based on our classification, less than one-quarter of Puerto Rican adults work in the free enterprise segment of the economy. ${ }^{6}$

Low levels of work experience in free enterprise activity are potentially important for at least three reasons. First, jobs in the free enterprise segment probably require somewhat different skills and work habits than jobs in the public and regulated sectors. This view resonates with evidence that experience-related human capital is imperfectly portable across industries (Neal, 1995 and Parent, 2000) and evidence that many displaced workers suffer large, persistent earnings losses (e.g., Jacobson et al., 1993).

\footnotetext{
${ }^{5}$ We have not systematically subtracted non-governmental employees in all industries for which public sector employment exceeds a specified threshold, although that would be a reasonable approach. A separate issue involves the manner of achieving consistency between Puerto Rico and the United States in defining the free enterprise segment. We opted for a uniform list of industries that are designated as outside the free enterprise segment in both Puerto Rico and the United States. An alternative approach would allow the designated list of industries to differ between the two, recognizing industry-level differences between Puerto Rico and the United States in public sector employment shares and the extent of government involvement.

${ }^{6}$ Excluding Pharmaceuticals, the percentage of Puerto Rican adults working in the free enterprise segment of the economy is $21.0 \%$ in 1980, 23.7\% in 1990 and $22.9 \%$ in 2000.
} 
Thus, the skills and earnings potential acquired through work experience in the public and regulated sectors may not easily transfer to free enterprise work activity.

Second, private sector work experience is a more powerful incubator of entrepreneurial skills and ambitions than jobs in the public and regulated sectors. This proposition finds support in previous research on the propensity to become a business owner and the determinants of business success. Studies consistently find that self employment and business ownership rates are much higher among children of business owners. ${ }^{7}$ Based on U.S. data, Fairlie and Robb (2003) report that half of all business owners had a self-employed family member prior to starting a business, where "family member" means a spouse, parent or guardian, sibling or other immediate family member. Moreover, their empirical investigation leads them to conclude that "the business human capital acquired from prior work experience in a family member's business appears to be very important for business success." Less than $2 \%$ of small U.S. businesses are inherited, according to Fairlie and Robb, consistent with the view that business experience rather than business transfer explains the strong intergenerational link in business ownership propensities.

Third, the nature of work experience, one's own and that of friends and family, probably plays an important role in shaping attitudes towards business regulation, taxation, public sector employment, and income redistribution. There is a greater belief in the propositions that "poverty is society's fault" and "luck determines income" in countries with higher social welfare spending (Alesina and Glaeser, chapter 7). And there is stronger support for the view that "it is the responsibility of the government to reduce income differences" in countries with a history of socialized production (Corneo and Gruener, 2002, Table 1). These cross-country patterns suggest that limited work experience in free enterprise activity leads to limited political support for economic reforms that would aggressively expand private business activity and employment.

Despite Puerto Rico's huge shortfall in overall employment rates, the percentage of adults who work in the public sector was actually larger on the island than on the mainland in 1980 and 1990. For example, 13.2\% of adult Puerto Ricans worked in the

\footnotetext{
${ }^{7}$ Recent studies on this issue include Dunn and Holtz-Eakin (2000), Hout and Rosen (2000), and Fairlie and Robb (2003).
} 
public sector in 1990, compared to $11.6 \%$ of U.S. adults. The situation reversed over the next decade as public sector employment rates in Puerto Rico fell sharply to 9.3\% of the adult population in 2000. Part, perhaps a large part, of the decline in Puerto Rico's public sector employment rates reflects the privatization of state-owned enterprises. ${ }^{8}$ The partial privatization of telecommunications in the 1990s faced strong resistance from labor unions that included a long strike and widespread sabotage. It would be useful to know how wages and employment fared in privatized Puerto Rican firms before and after privatization. It would also be useful to know whether Puerto Ricans who lost public sector jobs during the 1990s experienced particular difficulties in finding new jobs in the private sector. We are unaware of direct evidence on these issues.

The public sector continues to absorb a bigger percentage of more educated persons on the island, and a much bigger percentage of more educated workers. Consider collegeeducated persons in 2000. In Puerto Rico, 24\% work in the public sector, $41 \%$ work in the private sector, and the rest are not employed. In the United States, 20\% work in the public sector and $63 \%$ work in the private sector. Put differently, the public sector absorbs $37 \%$ of college-educated workers in Puerto Rico compared to $24 \%$ in the United States. As shown in Panel C of Table 1, the share of college-educated persons working in Puerto Rico's public sector is even larger, indeed much larger, in 1980 and 1990, and the share working in the private sector is smaller. Of course, the population fraction with a college education is lower on the island. The upshot is that college-educated persons with private-sector work experience are much more abundant in the United States that in Puerto Rico. If higher education produces forms of human capital that are useful for entrepreneurial endeavors in the private sector, then Puerto Rico faces another type of large human capital deficit compared to the United States - larger than a simple comparison of schooling levels would suggest. We attach numbers to this point below.

\subsection{Employment Rates by Educational Attainment}

Puerto Rico's employment shortfall is most acute for less educated persons. Tables 2 and 3 describe the situation for men and women, respectively, based on household census

\footnotetext{
${ }^{8}$ We have been unable to obtain the data required to quantify the role of privatizations in the decline of public sector employment. However, we have been informed that privatized enterprises routinely hired government employees, often as a requirement to secure government contracts.
} 
data for 1980, 1990 and 2000. The tables show that U.S. employment rates exceed Puerto Rican rates in every schooling category except for college-educated women in 1980. For both men and women, there is a clear pattern of bigger gaps in the employment rate at lower levels of schooling.

Less educated persons are also relatively abundant on the island. Hence, in an accounting sense, one can attribute a sizable portion of the U.S.-Puerto Rican employment gap to lower schooling levels on the island. But the data weigh heavily against an explanation for Puerto Rico's employment shortfall that focuses on lower schooling levels as the main reason for lower employment rates. U.S.-Puerto Rican gaps in the employment rate are remarkably large within schooling groups. In the 2000 Census, every schooling group shows a double-digit gap in the employment rate. For Puerto Ricans with a high school diploma or GED equivalent (the median schooling level among Puerto Rican adults in 2000), the employment rate is 47 percent for men and 25 percent for women. The corresponding U.S. figures are 75 percent for men and 62 percent for women.

Moreover, schooling levels cannot account for the time-series behavior of Puerto Rican employment. According to Census data, Puerto Rico's employment rate fell by 4.8 percentage points between 1990 and 2000 from an already low base. It fell by 3.6 percentage points relative to the United States over the same period. These absolute and relative declines in Puerto Rico's employment rate coincide with rising schooling levels among Puerto Rican adults and a sharp narrowing of the schooling gap vis-à-vis the United States. The labor force survey (Figure 1) presents a more favorable picture of Puerto Rico's employment performance in the 1990s, but even these more favorable data suggest that dramatic gains in schooling are associated with very modest increases in the rate of employment.

Tables 2 and 3 also show that the enormous U.S.-Puerto Rican work experience gap holds in terms of hours worked as well as employment rates. For employed men, U.S. work time exceeds Puerto Rican work time by 220 to 270 hours per year. This sizable gap in hours worked per employed amplifies the work experience gap calculated from employment rates. For women, annual work hours per employed person are somewhat greater for Puerto Rico in 1980 but somewhat less in 2000. On net, the hours worked data 
reinforce and strengthen the view that Puerto Rican residents have accumulated a huge shortfall in work experience relative to U.S. residents.

Table 4 combines data on the population schooling distribution and employment rates by schooling levels to calculate the percentage of adults who are college educated and working in the private sector. Relative to the population, college-educated persons working in the private sector are nearly three times more abundant on the mainland than on the island in 1980, and roughly twice as abundant in 1990 and 2000. A similar pattern holds with respect to college-educated persons working in the free enterprise segment of the economy. Recall from our earlier discussion that we designate the same set of industries as comprising the free enterprise segment in Puerto Rico and the United States, even though the government role at the industry level looms larger in Puerto Rico. For this reason, we think Table 4 understates the relative scarcity of college-educated Puerto Ricans engaged in free enterprise work activity.

\subsection{The Structure of Public Sector Employment}

Table 5 provides a closer look at public sector employment in Puerto Rico and provides additional comparisons to the United States. In 1980, the percentage of workers with government jobs was nearly twice as big in Puerto Rico. The public sector share of Puerto Rican employment fell from 34 percent in 1980 to 31 percent in 1990 and 25 percent in 2000. Nevertheless, the public sector continues to account for a much bigger fraction of overall employment on the island. The entire gap, and then some, between Puerto Rican and U.S. public sector shares reflects bigger employment shares at the subfederal government level. In fact, the discrepancy arises almost entirely at the state and commonwealth levels of government. The share of total employment accounted for by local governments is similar on the island and the mainland.

Does Puerto Rico's high public employment share reflect an industry mix that leans toward goods and services that, even in the United States, tend to be supplied by the public sector? (An industry mix effect.) Or, does Puerto Rico's high public employment share reflect a bigger government role within narrowly defined industries? (A withinindustry effect) To address these questions, express the public sector share of employment in Puerto Rico and the United States as 


$$
P U B^{P R}=\sum_{i} S_{i}^{P R} P U B_{i}^{P R} \text { and } P U B^{U S}=\sum_{i} S_{i}^{U S} P U B_{i}^{U S}
$$

where $S_{i}$ is the share of employment in industry $i$, and $P U B_{i}$ is the public sector share of employment for industry $i$. Next, evaluate Puerto Rico's industry-level government employment shares at the U.S. industry distribution of employment:

$$
P U B^{P R}(\text { U.S. Industry Distribution })=\sum_{i} S_{i}^{U S} P U B_{i}^{P R}
$$

Also, evaluate the U.S. industry-level government employment shares at the Puerto Rican industry distribution of employment:

$$
P U B^{P R} \text { (U.S. Government Shares) }=\sum_{i} S_{i}^{P R} P U B_{i}^{U S}
$$

By calculating (2) and (3), we can quantify the contribution of the industry mix effect and the within-industry effect to the U.S.-Puerto Rican difference in the public sector share of overall employment. We carry out these calculations using detailed Census classifications into 232 to 264 distinct industries, depending on year.

The results of calculating (2) and (3) appear in the rightmost two columns of Panel A in Table 5. The basic story is similar for each Census year: the industry mix effect accounts for about $60 \%$ of the U.S.-Puerto Rican difference in public sector employment shares, and the within-industry effect accounts for about $40 \%{ }^{9}$ Recall that the U.S.-Puerto Rican gap in the public sector share of overall employment has been shrinking. Hence, we infer that Puerto Rico's economy has been evolving toward a less government-intensive industry mix relative to a contemporaneous U.S. benchmark, and at the same time, the average U.S.-Puerto Rican gap in public sector employment shares within industries has also been shrinking.

Panel B of Table 5 illustrates the latter point with specific examples. As of 1980, Puerto Rico's public sector share of employment is much larger in several sizable industries, involving a broad range of production activities. After 1980, the public sector share of employment in these industries shrinks on the island and in the United States. The declines in within-industry public sector shares are bigger in absolute percentage terms for Puerto Rico. However, the 2000 Census data show that government

\footnotetext{
${ }^{9}$ The decomposition into between and within effects is not exact, but the cross product terms are small in these data.
} 
employment continues to play a relatively large role on the island in a broad range of industries that include Electric Light and Power, Sugar and Confectionary Manufacturing, Residential Care, Nursing Facilities, Child Day Care, Job Training, Hospitals, Museums and Zoos, and Sanitary Services. According to these data, there remains considerable room for shifting employment and production activity from the state sector to the private sector in many Puerto Rican industries.

\subsection{The Industry Structure of Employment}

Among the 50 states, there is a close relationship between average years of schooling in the adult population and the schooling intensity of the industry mix. In particular, the employment mix tilts toward industries that rely more heavily on highly educated workers in states with more educated populations. Figure 2 depicts this strong, perhaps unsurprising, relationship using household census data. We calculate the statelevel measure of schooling intensity in two steps. In the first step, we compute the schooling intensity of each Census industry as the mean years of completed schooling among all U.S. workers in the industry, weighting each worker in proportion to hours worked. In the second step, we compute a schooling intensity index for the state (or commonwealth) as the employment-weighted mean of the industry-level schooling intensity values. By construction, an industry has the same schooling intensity in all states and in Puerto Rico. So, the index quantifies the extent to which the employment distribution tilts toward schooling-intensive industries.

Figure 2 reveals a striking misalignment between Puerto Rico's industry structure and the schooling attainment of its population. Mean years of schooling among Puerto Rican adults fall well short of any state in each of the last three censuses. ${ }^{10}$ Nevertheless, the schooling intensity of Puerto Rico's industry mix exceeds that of two-thirds or more of the 50 states. ${ }^{11}$ In terms of schooling intensity, Puerto Rico's industry mix ranks 13 th out 51 in 1980 (comparable to Virginia, Minnesota, Delaware and Hawaii), 10th out 51 in 1990 (above Delaware and Vermont), and $16^{\text {th }}$ out of 51 in 2000 (tied with Utah and

\footnotetext{
${ }^{10}$ Ladd and Rivera-Batiz (2005) provide a detailed comparison of U.S. and Puerto Rican schooling levels.

${ }^{11}$ Lawrence and Lau (2005) provide complementary evidence that the factor content of Puerto Rican exports is out of line with its factor endowment mix. Using industry-level measures of factor intensity, they find that Puerto Rican exports are much more capital-intensive than U.S. exports and similar in terms of R\&D intensity and labor skill intensity, where compensation level proxies for skill.
} 
Washington). Thus the Puerto Rican economy has for decades failed to generate jobs that, in terms of educational requirements, fit the qualifications of the Puerto Rican population. $^{12}$

This finding provides an important clue regarding Puerto Rico's anemic employment performance and its especially low employment rates among persons with lower schooling levels. In an important sense, the "missing jobs" in Puerto Rico are to be found largely in labor-intensive industries that rely heavily on less educated workers. Table 6 provides additional evidence on this point. Consider Eating, Drinking and Lodging, an industry group that accounts for 5 or 6 percent of employment in the United States. Most workers in this industry group have relatively low schooling levels. ${ }^{13}$ Puerto Rico's share of employment in this industry group is less than any of the 50 states in 1980 and 1990 and near the bottom of the distribution in 2000. The story is similar but less pronounced for Entertainment and Recreation Services. To fully appreciate the glaring nature of Puerto Rico's employment shortfall in these industries, three facts should be kept in mind. First, Table 6 considers employment shares, but we showed earlier that Puerto Rico's employment rate is only 55-65\% of the U.S. rate. Hence, Puerto Rico's employment shortfall in these industries is much greater as a percentage of the working-age population. Second, Puerto Rico has a relative abundance of less educated persons to potentially fill jobs in these industries. And third, Puerto Rico is blessed with a tropical climate and interesting topography that could potentially attract many more visitors from the United States and elsewhere, visitors who would intensively demand the types of goods and services that these industries produce. In light of these last two points, the magnitude of Puerto Rico's employment shortfall in these industries is a

\footnotetext{
${ }^{12}$ A small caveat to this conclusion is worth a mention. The same economic policies that distort Puerto Rico's industry structure may also alter the mix of production activities within industries on the island relative to the mainland. In the case of Pharmaceuticals, Section 936 tax subsidies stimulated the sourcing of physical production to the island while the more schooling-intensive research and development activities remained on the mainland. For two reasons, we do not see this issue as a big concern in the interpretation of Figure 2. First, the scope for this type of outsourcing arises mainly in certain manufacturing industries. Second, the Section 936 subsidies are highly concentrated in a small number of capital-intensive industries that account for only a small share of employment. Pharmaceutical manufacturers, which received the bulk of Section 936 subsidies, account for only 2-3 percent of Puerto Rican employment in recent decades.

${ }^{13}$ Table A.2 in Davis and Henrekson (2005b) reports workers' mean schooling years for 61 industry groups based on data from the Current Population Survey for 1984 to 196. Eating and Drinking establishments rank 54 out of 61 industry groups on this measure of skill, and Hotels and Lodging rank 47.
} 
powerful testament to the decades-long failure of industrial and employment policy on the island.

One might hope that Puerto Rico's rising schooling levels would eventually eliminate any employment shortfall created by the misalignment of its industry structure. However, Figure 3 suggests that such a hope is largely in vain. We carry out the same type of exercise as before in Figure 3, except that we now relate the industry structure of employment to the schooling attainment of employed, rather than all, persons. For 1980 and 1990, Figure 3 tells a similar story to Figure 2. By 2000, however, the misalignment between the schooling intensity of Puerto Rico's industry structure and the schooling attainment of its workers has largely vanished. Puerto Rico remains an outlier in 2000 but no more so than Texas, California or New Mexico. Yet, as we have seen, the U.S.-Puerto Rican gap in the employment-population ratio remains enormous in 2000. In other words, Puerto Rico achieved a reasonable alignment between its industry structure and the educational attainment of its workers by 2000 - roughly in line with the relationship among the 50 states - but it did so by excluding the less educated from jobs.

One other fact, readily visible in Figure 1, belies the hope that Puerto Rico can educate its way out of a huge jobs shortage for less educated persons. Between 1980 and 2000, the U.S.-Puerto Rican gap in average schooling attainment among persons 16-65 years old shrank by roughly two thirds. Yet over the same twenty-year period, the Puerto Rican employment rate rose only slightly from $61 \%$ to $64 \%$ of the U.S. rate according to the labor force survey, and it fell relative to the U.S. rate according to the household census. If more education were the key to addressing Puerto Rico's employment shortfall, the island would have a spectacular record of employment growth in recent decades.

\subsection{The Size and Ownership Structure of Employment}

Table 7 reports the distribution of paid employees by establishment size in four major industry groups for Puerto Rico and the United States. ${ }^{14}$ These statistics derive from the Economic Census of 1997, an establishment-level census of all tax-paying business units

\footnotetext{
${ }^{14}$ Comparable statistics on the distribution of employees by firm size are not available for Puerto Rico in the Economic Census or other sources known to us.
} 
in covered sectors. In comparison to the United States, Puerto Rico's Construction and Manufacturing employees are considerably more concentrated at larger establishments. In contrast, its Retail Trade employees are dramatically less concentrated at larger establishments. Remarkably, only $36 \%$ of retail employees in Puerto Rico work at establishments with fifty or more paid employees, as compared to $76 \%$ on the U.S. mainland. The two employee size distributions are similar in Wholesale Trade, although Puerto Rico has smaller shares at the smallest and largest establishments. In short, there is no simple characterization of Puerto Rico's small business employment share, relative to the United States, that holds across major industry groups.

The Economic Census also provides limited information about the ownership structure of employment. As seen in Table 8, unincorporated enterprises account for very small shares of paid employees in Manufacturing. They account for bigger shares, ranging from 5\% to 24\%, in Construction, Wholesale Trade and Retail Trade. Notably, the share of paid employees at unincorporated enterprises in these industry groups is roughly twice as big in Puerto Rico as on the U.S. mainland. Retail Trade again presents a sharp contrast: about $16 \%$ of paid employees work for individual proprietorships in Puerto Rico, compared to only $6 \%$ on the U.S. mainland.

The Retail Trade figures for Puerto Rico are especially noteworthy in light of developments on the U.S. mainland in recent decades. Wal-Mart, Target, Staples, Best Buy, Home Depot and other national chains have propelled the introduction and diffusion of larger stores with greater product selection, lower prices, electronic credit-card processing, barcode scanners, and advanced inventory management techniques. ${ }^{15}$ In the process, they have transformed the U.S. retail sector, dramatically increasing productivity, and displacing thousands of smaller and independent retail enterprises. Using micro data from the U.S. Census of Retail Trade, Foster et al. (2004) document that retail establishments owned by large national chains have higher labor productivity than establishments owned by single-unit firms. They also show that essentially all of the productivity growth in the U.S. retail sector between 1987 and 1997 reflects the

\footnotetext{
${ }^{15}$ For description and analysis of these developments in the U.S. Retail Trade sector, see Nakamura (1999), McKinsey Global Institute (2001), Sieling, Friedman and Dumas (2001), Foster, Haltiwanger and Krizan (2004), Hausman and Leibtag (2004), Basker (2005ab), and Holmes (2005).
} 
displacement of less productive single-establishment retail firms by the entry of more productive, typically larger, establishments owned by national chains.

Wal-Mart, in particular, has been at the forefront of these developments and has attracted attention in several careful studies. McKinsey Global Institute (2001) describes Wal-Mart's role in the transformation of the retail sector this way:

In general merchandise retailing, productivity growth accelerated after 1995 because Wal-Mart's success forced competitors to improve their operations. In 1987, Wal-Mart had just 9 percent market share, but was 40 percent more productive than its competitors. By the mid-1990s, its share had grown to 27 percent while its productivity advantage widened to 48 percent. Competitors reacted by adopting many of WalMart's innovations, including large scale ("big box") format, economies of scale in warehouse logistics and purchasing, electronic data interchange (EDI), and wireless barcode scanning.

Tables 7 and 8 imply that Puerto Rico's retail sector lags well behind the mainland in the type of creative destruction process documented by Foster et al. (2004) and McKinsey Global Institute - to the detriment of its residents. Some of the most powerful consumer benefits of the U.S. retail transformation take the form of lower prices. Hausman and Leibtag (2004) find that "Wal-Mart offers identical food items at an average price about 15\%-25\% lower than traditional supermarkets.” A complementary study by Basker (2005b) finds that the entry of a new Wal-Mart store leads to significantly lower prices at competitor stores in the same city. Basker (2005a) provides evidence that the entry of a new Wal-Mart store leads to a modest net increase in county-wide employment.

Why has Puerto Rico lagged in the transformation of its retail sector? The permitting process for new construction and real estate development projects has slowed the transformation of the retail sector for reasons explained in Section 4 below. Municipal government oversight of retail store entry and location decisions has also played a role, as explained in Section 3.4 below.

\subsection{Informal Sector Employment}

The underground, shadow or informal economy refers to output and incomes generated in market production activity that are not declared to the government, particularly the tax and regulatory authorities. Standard establishment-based measures of 
output and employment are unlikely to capture underground activity. In principle, household surveys capture employment in the underground economy, but respondents may be reluctant to provide information about employment in illegal or undeclared activities. This leaves open the possibility that official estimates of Puerto Rico's employment rate are so low, because they miss a high rate of employment in the underground economy.

Estudios Técnicos (2004) provides a figure for informal sector employment in Puerto Rico that is 20.5 percent as large as the official labor force measure. However, the figure is based on a methodology that attributes the U.S.-Puerto Rican gap in labor force participation rates to the U.S.-Puerto Rican gap in informal sector employment. So the $20.5 \%$ figure is essentially a restatement of the participation (and employment) gap, and it cannot tell us how much of the measured employment gap reflects informal sector activity. Direct, survey-based evidence on informal sector employment for a random sample of Puerto Rican residents is lacking. The lack of direct evidence leaves us unable to confidently adjust the U.S.-Puerto Rican employment gap for informal activity.

It is unlikely, however, that the informal sector accounts for the bulk of the U.S.Puerto Rican employment gap, as measured by standard labor force surveys. Many persons who work off the books for a portion of their income also hold formal sector jobs, and they already show up in measured employment. Many other persons who work only in the informal sector are also counted as employed in household surveys. Hence, any U.S.-Puerto Rican gap in the rate of missing employment is smaller in magnitude, probably much smaller, than the U.S.-Puerto Rican difference in informal sector employment rates. In addition, the available evidence suggests that underground activity in Puerto Rico has declined relative to GDP in the past quarter century, and moved closer to U.S. levels. ${ }^{16}$

\footnotetext{
${ }^{16}$ Bosworth and Collins (2005, Appendix B) report that the revenue gap between income in the national accounts and income declared for tax purposes diminished sharply after 1976 in Puerto Rico. This trend suggests that underground activity motivated by tax avoidance activity also declined. In recent years Puerto Rico's revenue gap as a percentage of GDP has declined to levels only a few percentage points above the U.S. level. Another standard indicator based on electricity usage suggests that underground activity in Puerto Rico fell sharply relative to GDP in the 1980s, and then partly recovered in the 1990s.
} 


\section{Policy Influences on Business Development and Employment Growth}

\subsection{The overall policy and institutional environment}

Compared to many middle-income countries, Puerto Rico enjoys strong

institutions and favorable economic policies. By virtue of its association with the United States, Puerto Rico benefits from sound monetary policy, a stable financial environment, and open migration to and from the U.S. mainland. Puerto Rico's international trade regime is largely governed by U.S. trade policies and World Trade Organization (WTO) rules. As a result, tariffs on traded goods and services are relatively low and somewhat insulated from manipulation by political authorities on the island. Price controls are minimal, and there are no burdensome currency regulations or capital controls. Many aspects of the overall economic environment are shaped by U.S. laws.

Set against these favorable features of Puerto Rico's economic environment are several unfavorable ones. There are peculiarities and loopholes in the application of U.S. trade laws that raise effective trade barriers. Section 936 and other tax subsidies have distorted Puerto Rico's industrial structure. Minimum wage laws raise the cost of employing less skilled workers. An extensive role for government transfer payments undermines work incentives. An inefficient and cumbersome regime for business licenses and permits impedes construction activity, new business development and cost-effective operation of existing businesses. More generally, many government services are of poor quality, and there is a culture of dependence on the government as a source of employment and favors. In addition, the traditional prevalence of state-owned enterprises has probably softened competitive pressures and lowered productivity throughout much of the economy. We discuss each of these features in greater detail below.

Table 9 shows business climate indicators compiled by the World Bank for Puerto Rico and other countries. According to these indicators, Puerto Rico compares favorably to the Latin American and Caribbean region in terms of the costs of starting a formal business, the regulation of employment, institutional support for credit markets, and the costs of closing an insolvent business. The Puerto Rican business climate is roughly comparable to the average OECD country according to many of the indicators, and there is greater employment flexibility on the island. The most unfavorable aspects of Puerto 
Rico's business climate according to the World Bank indicators pertain to the cost and difficulty of enforcing commercial debt obligations.

The picture of Puerto Rico's business climate suggested by Table 9 is too rosy in our view, because it fails to capture several factors that increase day-to-day operating costs, raise artificial barriers to entry and expansion, and cultivate a rent-seeking business culture. Unfortunately, these factors are difficult to quantify. Hence, portions of our discussion below rely on descriptive and anecdotal evidence drawn from a variety of sources, including informal interviews with business persons and government officials.

\subsection{Trade Protectionism}

The U.S. Jones Act raises the cost of trade between Puerto Rico and the United States by requiring the use of American vessels for all goods shipped by sea between Puerto Rican and U.S. ports. The effect is equivalent to a tariff on Puerto Rican imports from the United States and on U.S. imports from Puerto Rico.

Puerto Rico has also established protectionist measures that are incompatible with WTO rules for international trade. For instance, Law 69 of 2002 levies a higher excise tax for high-volume producers than for low-volume producers. High-volume producers tend to be foreign, and low-volume producers tend to be local. The Supreme Court of Puerto Rico has ruled that Law 69 does not discriminate against foreign producers, because it does not explicitly target foreign firms for higher tax rates. ${ }^{17}$ In recent cases involving Japan, Korea and Chile, however, the WTO has ruled that what matters is the outcome, not the precise manner in which local authorities structure a tax (Rodriguez Santiago, 2005).

Puerto Rico also has other "buy local" laws with a strong protectionist element. These laws support certain local enterprises, but they also distort purchase decisions, lessen competitive pressures, and lower government tax revenues. For example, Law 110 (August 2001) provides for a 25\% credit on Puerto Rican corporate income taxes for the purchase of eligible products manufactured and sold in Puerto Rico. Law 169 (December 2001) contains similar provisions for manufactured goods that are purchased for export.

\footnotetext{
${ }^{17}$ U.S. federal courts did not assume jurisdiction in this matter, leaving it to Puerto Rican courts.
} 
A June 2005 executive order issued by the governor requires government agencies to earmark 15 percent of their purchase contracts for small and mid-sized local enterprises.

\subsection{Tax Subsidies that Distort the Structure of Production and Employment}

Tax incentives for industry have a long history in Puerto Rico. Section 936 of the U.S. tax code "largely exempted U.S. corporations from paying federal tax on income earned by their Puerto Rican subsidiaries. Puerto Rico has a parallel tax subsidy program effectively exempting 936 corporations from Puerto Rican income taxes as well." 18 (Hexner and Jenkins, 1998) At one time, these tax subsidies were seen as useful tools for stimulating employment in labor-intensive industries and easing Puerto Rico's unemployment problems. In practice, Section 936 tax subsidies proved most attractive in capital-intensive manufacturing industries that produce proprietary products with big price markups over marginal costs. Products of this type facilitate tax-minimizing transfer prices and profit shifting between jurisdictions with different effective tax rates.

According to a study by the U.S. General Accounting Office (1993) cited in Bosworth and Collins (2005), Section 936 tax subsidies to U.S. corporations with Puerto Rican operations amounted to $\$ 2.6$ billion in 1989 or $13 \%$ of Puerto Rico's GDP. One view is that subsidies of this magnitude profoundly influenced Puerto Rico's economy and industrial structure. Another view is that the Section 936 subsidies mainly reflect paper transactions with little impact on the Puerto Rican economy but a high cost to the U.S. treasury. Both views contain an important element of truth. On the one hand, Bosworth and Collins make a convincing case that a large portion of the Section 936 subsidies in recent decades reflects income shifting by U.S. corporations through distorted transfer prices and other means. On the other hand, it is widely acknowledged that pharmaceutical firms sourced much of their production activity in Puerto Rico to exploit Section 936 subsidies. The employment statistics for Pharmaceuticals in Table 6 support this view. The share of employment accounted for by the Pharmaceuticals

\footnotetext{
${ }^{18}$ Section 936 was established by the U.S. Tax Act of 1976, but precursors in the U.S. and Puerto Rican tax codes date back several decades. Section 936 tax credits have been phased out as of 2005, but U.S. firms can still defer U.S. corporate income tax on Puerto Rican earnings by converting their Puerto Rican operations into controlled foreign corporations. See Odishelidze and Laffer (2004, pages 174-180) for a useful synopsis of the evolution of Section 936 and related features of the U.S. and Puerto Rican tax codes. Pelzman (2002) provides a detailed and highly informative description.
} 
industry in Puerto Rico is about ten times larger than in the United States as a whole and two or three times larger than in any single state.

If the goal is to stimulate employment, one would be hard pressed to devise a less effective, more costly tool than Section 936 subsidies or similar tax subsidies. Hunter (2003, Figure 4) reports that, in 1993, $98.5 \%$ of Section 936 tax credits for the Puerto Rican operations of U.S. corporations accrue to Manufacturing and Public Utilities. These are among the most capital-intensive sectors of the economy. According to Bosworth and Collins, $60 \%$ of the subsidies accrue to the manufacture of chemicals and allied products such as medicines. Hexner and Jenkins (1998) refer to a 1992 GAO study that finds "drug companies with manufacturing operations in Puerto Rico received tax benefits worth $\$ 72,788$ for each job paying an average of $\$ 26,471 . "$

\subsection{Tax Subsidies, Entry Barriers, and Rent-Seeking Behavior}

Section 936 tax subsidies merit special attention because of their enormous magnitude, historically, and their impact on the structure of employment and output. But they are only part of a larger story. The Puerto Rican tax code and regulatory system abound with provisions that cater to special business interests. Some provisions take the form of targeted tax breaks, others restrict business entry and expansion, and others involve licensing requirements and burdensome regulations that favor incumbents over potential rivals. In this climate, profitability and survival often hinge on obtaining and exploiting special tax breaks and regulatory advantages. The result is a complicated web of policy-induced financial incentives that helps to sustain a rent-seeking business culture and an overly intrusive role for the government.

As an illustration, Table 10 presents a list of business incentives enacted into law from August 2001 to August 2002. ${ }^{19}$ Various provisions aim to encourage the industrial, agricultural and export sectors, the film industry, call center operations, stagnant municipalities, and the employment of high skill workers and handicapped workers. These various provisions, which add to a large set of older incentive programs, exhibit

\footnotetext{
${ }^{19}$ The number of industrial incentives enacted into law during this period is unusually large, but the characteristics of the incentives described in Table 10 are typical of other periods as well. We do not claim that the list in Table 10 is exhaustive for the period covered. See Cao Garcia (2004) for an historical account of federal and home-grown tax incentives in Puerto Rico, and Alm and Cao Garcia (2005) for a comparative analysis of Puerto Rico's tax system.
} 
several noteworthy characteristics. First, they typically benefit special business interests. Second, the form of the benefits, e.g., credits and deductions on business taxes, makes it difficult to assess the magnitude of the subsidy and the likely drain on the government treasury. Third, the incentive provisions often enlarge the powers of the government bureaucracy, especially at the commonwealth level. Fourth, several of the industrial incentives erode the revenue base at the municipal level. Examples include exemptions from local property taxes and municipal patent requirements. Fifth, some provisions contain an element of trade protectionism, such as tax exemptions for the purchase of Puerto Rican manufactures. Finally, when taken as a whole, Table 10 suggests that rent seeking is an important feature of the Puerto Rican business climate. Much effort and large expenditures are devoted to lobbying the legislature for special-interest provisions. The bills actually passed into law represent a small sample of the proposals that shuttle around the legislature.

Rent seeking behavior extends beyond tax breaks and subsidized credit to a variety of entry barriers that protect incumbents and local business interests. Some of the most important barriers arise at the municipal government level. Businesses in Puerto Rico must usually obtain a patent from the local municipality to operate within its boundaries. The steps required for obtaining municipal patents look straightforward on the books, but, in practice, the process can be plagued with difficulties. A key problem is that a patent is granted only for a particular location, as determined by the municipal authority. Municipalities often grant patents only for slow business areas, effectively protecting incumbents in desirable locations.

Other entry barriers arise at the commonwealth level. A recent federal appeals court decision explains how entry barriers work for retail pharmacies in Puerto Rico. ${ }^{20}$ Law No. 189 of July 29, 1979 requires a proposed new pharmacy establishment to obtain a Certificate of Need and Convenience from the Secretary of the Puerto Rico Health Department. Certificates are routinely granted in the absence of local merchant opposition, but they are subjected to a costly and lengthy legal proceeding if any "affected party", invariably a rival pharmacy establishment, opposes the proposed pharmacy. In such cases, the certificate is often denied, as it was for several Walgreen

\footnotetext{
${ }^{20}$ See United States Court of Appeals for the First Circuit (2005b).
} 
outlets. Walgreen filed suit in federal court, claiming that Law 189 amounted to an unconstitutional infringement on interstate commerce, and eventually prevailed at the appellate level. The Walgreen matter pertained to pharmacies only, and similar certification requirements remain in effect for other health care facilities.

More generally, licensing requirements restrict entry into many professions, services and business activities. In the past decade, there has been a wave of lobbying efforts to establish new professional licensing requirements and collegiate associations with compulsory dues. One example involves the legal requirements to produce a public performance such as a theatrical production or a music concert. The current requirements under Law 182 are reasonably straightforward: a \$20 license fee, a certificate of good conduct, evidence that tax payments are current, and the posting of a bond or insurance policy. Law 182 also provides for a $\$ 10,000$ fine for anyone who produces an event without a license. House bill 1460, approved by the House with bipartisan support on June 21, 2005, would raise entry barriers by requiring that a producer have five years of experience as a promoter, work at least one year with an established producer, and hold a specified college degree. In addition, the proposed law would create a Puerto Rico College of Public Performance Producers (Colegio de Productores de Espectáculos Públicos) that would have the power to license, regulate, sue, and investigate the actions of collegiate members. Similar legislation is currently under review in the Senate. Other recent examples of efforts to erect professional entry barriers include Senate Project 1842 for psychologists, a proposed College of Journalists for newspersons, and House Project 3755 for economists. This last one is favored by the Puerto Rico Association of Economists, suggesting that economists are just as ready to erect entry barriers in their own interests as anyone else.

The similarity of these licensing requirements and collegiate organizations to medieval guilds is striking. These measures are sold as arrangements that ensure quality and protect local interests against foreign interests or large companies. Their clear economic effect, however, is to restrict competition and raise prices for consumers. Adam Smith developed this theme more than two centuries ago in his vigorous critique of mandatory apprenticeships and other restrictions on entry into cutlery, weaving and other 
trades in $18^{\text {th }}$ century Britain. ${ }^{21}$ More recently, Djankov et al. (2001) examine data for start-up firms in 85 countries. They report that countries with heavier entry regulation have more corruption and larger underground economies but not better quality of private or public goods. The implication is that stronger entry regulation accentuates corruption and expands the underground economy without any compensating improvement in the quality of goods and services.

\subsection{Taxes on Labor Income and Consumption}

Taxes on labor income and consumption expenditures encourage households to substitute away from the legal market sector in favor of untaxed activities - leisure, household production, and the underground economy. Substitution away from the legal market sector is relatively easy for certain goods and services such as meal preparation and cleaning services, and relatively difficult for others such as automobile production and surgery. Hence, high tax rates on labor and consumption discourage work activity in the legal market sector, and they systematically alter the mix of market production activity. Tax-sensitive sectors include eating and drinking establishments, laundry and cleaning services, child care, consumer repair services, domestic household help, and most personal services. As suggested by this list of examples, tax-sensitive sectors tend to rely heavily on workers with lower schooling and lower wages. It follows that high tax rates on labor and consumption have disproportionately large negative effects on the demand for less skilled workers.

Davis and Henrekson (2005a) investigate these issues in a sample of rich countries. They find that higher tax rates on labor and consumption lead to less work activity in the legal market sector, a bigger underground economy, and an altered industry mix. ${ }^{22}$ The estimated effects are quite large. Consider, for example, a 12.8 percentage point between-country difference in the tax rate, a unit standard deviation in the cross section of their sample. Using data for the mid-1990s and their preferred specification, they find that a tax rate increase of this size leads to 122 fewer hours

\footnotetext{
${ }^{21}$ See Book I, chapter X, part II in The Wealth of Nations. See Carlton and Perloff (2000, pages 74-76) for a modern analysis of the adverse price, output and cost effects of artificial entry restrictions.

${ }^{22}$ Many other studies also investigate the role of tax rates in cross-country differences in work activity and the size of the underground economy. See Davis and Henrekson (2005a) for references to this literature.
} 
worked per adult per year in the legal market sector, a drop of 4.9 percentage points in the employment-population ratio, and a rise in the underground economy equal to $3.8 \%$ of GDP. It also lowers by 10 to 30 percent the economy-wide share of production and employment in tax-sensitive sectors such as eating, drinking and lodging establishments. As Davis and Henrekson stress, these estimates reflect the direct effect of taxes on labor supply and labor demand plus the effects of tax-funded welfare and social insurance programs on labor supply incentives.

The impact of tax-funded transfer programs is of particular concern in Puerto Rico, because so many residents rely on government transfers as a major source of income. As analyzed in detail by Burtless and Sotomayor (2005) and Enchautegui and Freeman.(2005), these transfer programs often confront recipients with very high implicit tax rates if they move from welfare to work. On the U.S. mainland, earned income tax credits for working families mitigate the adverse labor supply incentives introduced by means-tested transfer programs. Puerto Rican residents are not eligible for earned income tax credits, because they do not pay federal income taxes.

\subsection{Minimum wage laws}

The U.S. Federal Fair Labor Standards Act (FLSA) regulates minimum wages and working conditions for covered workers. It has applied to Puerto Rico since its inception in 1938, but for decades the FSLA allowed for less extensive coverage and lower minimum wages in Puerto Rico. Starting in 1974, amendments to the FLSA increased coverage in Puerto Rico and gradually brought the Federal minimum for Puerto Rico into line with the U.S. minimum. Since 1983 Puerto Rican employers have faced essentially the same minimum wage requirements as U.S. employers (Castillo-Freeman and Freeman, 1992). The current Federal minimum of $\$ 5.15$ per hour for covered workers is about $30 \%$ of the average hourly wage in the United States and more than $60 \%$ of the average hourly wage in Puerto Rico. ${ }^{23}$ The Federal minimum has also been quite high historically relative to the average wage in Puerto Rico.

\footnotetext{
${ }^{23}$ Puerto Rico's average hourly wage is about $\$ 8.00$. Table 620 in U.S. Bureau of the Census (2005) reports an average hourly wage of $\$ 17.35$ for the United States in 2002.
} 
There is compelling evidence that minimum wage laws have profoundly affected the earnings distribution in Puerto Rico. ${ }^{24}$ For example, Castillo-Freeman and Freeman (1992) report that half of all covered workers in 1979 were paid at the prevailing U.S. minimum of $\$ 2.90$ per hour and another $13 \%$ were paid within 10 cents of the U.S. minimum. They also show that the increase in the Federal minimum from \$2.90 in 1979 to $\$ 3.35$ in 1983 had a pronounced effect on the shape of the earnings distribution.

The evidence regarding employment effects is much less clear cut. Based on an investigation of aggregate and industry-level data, Castillo-Freeman and Freeman conclude that the extension of the U.S. minimum to the island starting in 1974 caused “massive job losses” and greatly altered Puerto Rico’s industry mix. ${ }^{25}$ However, Krueger (1995) revisits the same data and concludes that the evidence regarding employment effects is "fragile" and "surprisingly weak." He shows that the estimated employment effects of Castillo-Freeman and Freeman are sensitive to reasonable alternatives for the empirical specifications and estimation methods. In short, the existing literature has reached no clear conclusions about the employment effects of minimum wage requirements in Puerto Rico.

Previous studies are largely silent about the longer term employment consequences of minimum wage requirements. This is a major drawback for the purposes of policy analysis, because the disemployment effects of minimum wage requirements are probably (much) larger in the longer term. It takes time to substitute away from low skill labor in response to mandatory wage floors. These substitution responses can take the form of higher capital-labor ratios, greater reliance on relatively skilled workers, and the adoption of labor-saving technology. Even with fixed factor intensities and unchanging technologies, disemployment effects mount over time if minimum wage requirements operate on the entry margin for new employers and new job positions. Given the overwhelming evidence that minimum wage laws have pushed up the lower half of Puerto Rico's wage distribution, it is highly likely that they also slowed the entry of new employers and the creation of new jobs for less skilled workers. In this regard, the evidence in Figure 2 is highly suggestive: Puerto Rico's missing jobs are concentrated in

\footnotetext{
${ }^{24}$ See Reynolds and Gregory (1965), Santiago (1989) and Castillo-Freeman and Freeman (1992).

${ }^{25}$ Santiago (1989) reaches similar conclusions based on a different approach to the aggregate time series.
} 
industries with relatively low schooling requirements. Employment in these industries is much more likely to be depressed by minimum wage requirements than employment in schooling-intensive industries.

Slow-working disemployment effects also arise through the impact of minimum wage requirements on the accumulation of work-related skills, as analyzed by Hashimoto (1982) and Mincer (1984), among many others. The skill accumulation effects work through two main channels. First, wage floors can reduce employment and hours directly, lowering work experience. Second, even when there is no direct effect on employment and hours, a binding wage minimum reduces the scope for learning and training on the job. For both reasons, workers then accumulate marketable skills more slowly. The result is a reduction in future earnings capacity and weaker attachment to the labor market, as recently emphasized by Neumark and Nizalova (2004). ${ }^{26}$ Longer term effects on labor market attachment are of particular concern when means-tested government transfer payments prop up reservation wages, as they do in Puerto Rico for a large fraction of the population. In summary, there are good reasons to think that the application of U.S.-level minimum wages has had a large negative impact on the rate of employment in Puerto Rico and on the accumulation of marketable skills among Puerto Rican residents.

\subsection{Other labor market regulations}

Private business owners and public sector managers in Puerto Rico frequently complain about an inability to address worker abuse of labor market regulations. There are important abuses pertaining to vacation time, sick leave, and worker dismissal. For example, employee claims of work-related stress are routinely endorsed by medical authorities without serious examination. As another example, the law mandates twelve days of sick leave per year for employees. However, employees are required to submit a medical report only if absent from work for more than two consecutive days. Many workers abuse the system by claiming health-related absences two days at a time up to

\footnotetext{
${ }^{26}$ Previous research provides little direct evidence on the longer term effects of minimum wage requirements, but the work by Neumark and Nizalova (2004) is an exception. They present evidence that exposure to higher minimum wage requirements at young ages leads to lower earnings and fewer work hours later in life for U.S. residents. The estimated effects are sizable: one additional year of exposure as a teenager to an 11 percent increase in the minimum wage above the level of the Federal minimum lowers earnings by $1.9 \%$ at ages 25-29. Reduced hours at ages 25-29 account for about one-quarter of the earnings reduction.
} 
the maximum number of days per year. Health-related absences are not determined in advance, so business planning and the performance of work groups suffer from unscheduled absences. These unscheduled absences raise labor costs and discourage employment growth.

Other problems arise in connection with dismissals and long term leaves of absence. If an employee is granted a long term leave for health-related reasons, the rules of the State Security Fund (Fondo de Seguro del Estado, FSE) require the employer to keep the employee's post open for a full year. During that time, the employer need not pay wages but must pay social benefits. The rules also specify that the employer cannot phone the employee or the FSE to discuss the issue. As a result, it is difficult for the firm to plan and operate efficiently. Worker dismissal often ends in legal lawsuits, causing employers to refrain from legally justifiable dismissals due to incompetence at work or a business slowdown. In turn, the difficulty and cost of dismissing workers make employers reluctant to hire.

\subsection{The Effect of State-Owned Enterprises on the Competitive Environment}

As we documented in Section 2, the public sector accounts for a large but declining share of economic activity in Puerto Rico. This evidence raises two questions:

Historically, how has a large public sector affected the competitive environment in Puerto Rico? And, how is Puerto Rico's competitive environment likely to evolve in response to a declining role for the public sector? Definitive answers to these questions are beyond the scope of this paper, but we can draw on recent research to suggest some tentative answers. In this regard, our main point is twofold: a large role for the public sector lessens competitive pressures, and a lessening of competitive pressures yields lower productivity.

A large public sector lessens competitive pressures in the economy for several reasons. First, state-owned enterprises operate with "softer" budget constraints than private enterprises in the sense that financial distress is more likely to result in taxpayerfunded bailouts for public enterprises. Second, the private sector can rely on the profit motive and high-powered incentives much more readily and effectively than the public sector. Third, when public and private sector enterprises potentially compete in the same 
line of business, the state often restricts private sector entry or expansion opportunities in order to protect the public enterprise. The U.S. postal service - with its governmentgranted monopoly in the delivery of first-class mail - is a classic example.

Several recent studies provide evidence that greater competitive pressure leads to higher labor productivity. This research suggests that the beneficial productivity effects of competitive pressure work through a variety of channels that vary with circumstances. Galdon-Sanchez and Schmitz (2002) and Schmitz (2005) offer some of the most compelling evidence that competitive pressure can provide the impetus for dramatic productivity gains. Schmitz (2005) finds that an intensification of competitive pressure in the iron ore industry in the early 1980s led, within a few years, to a doubling of labor productivity at U.S. and Canadian mines. Work-rule reforms that cut overstaffing requirements in collectively bargained labor contracts drove most of the productivity gains. The exit of low-productivity mines and the adoption of new technology played minor roles. Schmitz and Teixeira (2004) study the privatization of state-owned iron ore mines in Brazil in 1989. Prior to privatization, about $60 \%$ of the industry was state owned. In the first few years after privatization, labor productivity doubled at newly privatized mines and, even more remarkably, previously private mines. These productivity gains were much larger than contemporaneous gains at iron ore mines in other countries. Several other studies produce evidence that an intensification of competitive pressure raises productivity by displacing less efficient producers, triggering the reallocation of factor inputs to higher value uses, and stimulating reform in work practices. $^{27}$

These observations suggest that a large public sector has suppressed productivity levels in Puerto Rico for decades. By the same logic, they suggest that the rapid downsizing of Puerto Rico's public sector in the 1990s is a potentially important source of long term productivity gains. This issue merits further attention by researchers and policy makers.

\footnotetext{
${ }^{27}$ See Eslaval et al. (2004), Holmes and Schmitz (2001), Markiewicz et al. (2004), Sivadasan (2003), and Syverson (2004).
} 


\section{The Permitting Process as a Barrier to Business Development}

\subsection{Our Approach to the Topic}

We now turn to the permitting process whereby the government oversees and regulates construction and real estate development projects, the commercial use of equipment and facilities, and the periodic renewal of various business licenses. To the best of our knowledge, there is little systematic research on the permitting process in Puerto Rico and no comprehensive sources of information about the process and its consequences. Persons with in-depth knowledge of the permitting process are reluctant to speak for attribution, because the topic is politically sensitive and because public statements could jeopardize their commercial interests. In some cases, concerns about potential legal perils may also dissuade statements on the record.

In light of these realities, we took the following two-pronged approach in our efforts to understand the functioning of the permitting process. First, we conducted informal interviews with more than one hundred persons who have expertise on or firsthand experience with the permitting process in Puerto Rico. Second, we sought to corroborate the claims and characterizations of interviewees by drawing on external public sources such as newspaper articles, judicial proceedings and government laws and regulations. The result, we believe, is a first-pass description and analysis that delivers some insights into how the permitting process in Puerto Rico raises the cost of doing business, corrodes the business and regulatory climate, hampers economic development, and undermines the drive for employment growth. Our discussion below focuses on the permitting process for construction and real estate development projects, but our interviews indicate that the problems we identify also plague the permitting process for the commercial use of equipment and facilities and the periodic renewal of business operating licenses.

Before proceeding, a few additional remarks about our interview process are in order. We conducted face-to-face interviews with about ten contractors and construction engineers, fifteen real estate developers and their employees, ten business persons with experience as clients of construction contractors and real estate developers, five lenders and employees of financial institutions, twenty current and former government office holders, fifteen attorneys and permit specialists, and thirty other persons comprised of 
small business owners and their employees, entrepreneurs, and academics with knowledge of the permitting process. We did not select the interviewees randomly. Instead, we initially approached and interviewed several experts on the permitting process, and these experts referred us to other potential interviewees. As we proceeded, we also independently contacted other persons to clarify particular issues or seek out additional information. Interviews varied widely in depth and duration. The average interview lasted about thirty minutes, but many others lasted no more than ten minutes, and several interviews took a few hours. Follow-up interviews to clarify particular questions typically took place by phone, and were usually brief.

\subsection{Overview of the Permitting Process}

The permitting process for construction and real estate development projects in Puerto Rico involves four main elements:

1. Consultation regarding the proposed project's location (consulta de ubicación), which requires approval by the Planning Board (Junta de Planificación), an arm of the Governor's office. Zoning variances and proposed exceptions to standard construction requirements are also treated at this stage.

2. The preparation and filing of environmental assessments and environmental impact statements. The latter are more detailed and extensive.

3. Applications to the Permits and Regulations Administration (Administración de Permisos y Reglamentos, or ARPE) for permits pertaining to construction, renovation, and the placement of signs and advertisements. These permits are required by law for project development, the construction of new facilities, the refashioning of sites when starting new businesses, and for merely putting up signs.

4. Applications for various use permits required to operate a completed or renovated facility. These use permits include health certificates and fire department endorsements.

This high-level overview suggests that the permitting process is reasonably straightforward, but the reality is far more complex and fraught with uncertainty, compliance costs, and delays. To help provide a sense of the complexity and uncertainty, 
Figure 4 (translated from Solá, 2004) depicts the main elements of the permitting process as diagrammed by an experienced construction engineer. It offers a bird's eye view of the permitting maze. The sheer number of government agencies with hands in the process provides some indication of the complexities and the potential for bottlenecks. Solá (2004) describes the process as follows:

There are at least thirty four (34) public agencies that intervene in the process, in at least one hundred nineteen (119) procedures and twelve (12) stages in obtaining construction permits...There are about sixty (60) sets of regulations (reglamentos) that regulate land development and construction, many of them, or the amendments to them, realized incoherently and without an integrated vision of the objectives of the regulation...The budget assigned to pay needed technical and management personnel and to adequately equip regulatory agencies and the reviewing units of the agencies providing endorsements is excessively low. It is therefore necessary to restructure the processes in all and each of the agencies simultaneously. Without adequate funding these tasks cannot be realized.

All industry participants interviewed for this study stressed that the permitting process has been a nightmare for a long time and remains so. Many interviewees remarked that construction and development projects must overcome a wide range of bureaucratic obstacles that can unexpectedly delay or derail a project in its initial stages, and after construction has begun. In the case of environmental reviews, many interviewees remarked that bureaucratic inaction, legal ambiguities and political uncertainties lead to overly long approval delays and uncertainties. Interviewees tend to agree with the statement that the permitting process requires more than incremental change. Instead, the predominant view is that effective reform requires a full scrapping of the existing system and a fresh set of rules and procedures.

\subsection{Project Approval, Zoning and Construction Variances, and Environmental Review}

Two government agencies oversee the regulation of construction and development projects: the Planning Board (or Junta) and ARPE. The Planning Board is responsible for guiding the island's overall economic, social and physical development. It 
prepares the Economic Report to the Governor and elaborates the government's fiscal, social and economic plans as well as its zoning and other regulations. The agency was created in the early 1940s as the brainchild of Governor Rexford Guy Tugwell, who made it the main government arm to control and plan development of the island.

The Planning Board has an explicit consultation role in the permitting process when there are requests for variances (variaciones) from existing construction regulations and zoning requirements. Variances arise when some aspect of the project does not abide exactly by the existing regulations and requirements, which is the case for most substantial projects. Approval of variances requires consultations with the Board as the first step in the permitting process. If a project does not involve any variances, the developer proceeds directly to ARPE, which oversees the operational process related to the granting of permits. ARPE was created in 1975 (Law No. 76 of June 24, 1975) as a spin-off from the Planning Board, which formerly undertook the operational functions now performed by ARPE. These two agencies now enter at different stages in the permitting process and have distinct roles.

If the Planning Board approves a project's location and all variances, ARPE takes over for the remainder of the process. It applies the regulations, laws, and ordinances that govern the use and development of land, the construction, use and alteration of buildings and structures, and the installation of signs and announcements (rótulos y anuncios). However, if some unapproved variance is detected by ARPE, the developer proposing the project must return to the Planning Board for additional consultations and decisions.

According to interviewees, consultations with the Planning Board typically require one to two years for the approval of a major construction or development project, and as much as four years. The next step, preliminary approval from ARPE, may take as little as one week for projects with no variances from existing regulations and zoning requirements, but major projects typically require another six to twelve months for approval by ARPE. As mentioned by several developers that we interviewed, environmental disputes can further delay the start of development projects for many years. One example is the Serene Coast project in the Piñones area of Loíza, first proposed in 1995. The developer originally presented an Environmental Assessment but, in response to a judicial proceeding, it submitted a more detailed Environmental Impact 
Statement in 1997. As of 2005, the project has yet to obtain Planning Board approval, reportedly because public agencies have not determined if the project abides by the Environmental Public Policy Law of 1970. In July 2005, the Department of Natural and Environmental Resources requested modifications to the project on environmental grounds. Opposition to the Serene Coast project by environmental groups set against strong support for the project by the mayor of Loíza suggests that a stalemate will continue for some time. ${ }^{28}$

\subsection{Centralization, Politicization and Corruption in the Permitting Process}

Key aspects of the permitting process - location consultation, zoning variances, ARPE permits, and environmental approvals - are centralized in the Governor's office. This anomalous state of affairs traces back to the creation of the Planning Board in the early 1940's under the administration of Governor Tugwell, an activist planner. Tugwell concentrated the power to grant location and use permits in his office as a planning tool. When the Environmental Quality Board was created in 1970, it was incorporated into the Governor's office as well. When the operational part of the permitting process was separated from the Planning Board to form ARPE, it was also kept in the Governor's office. Thus, new business activity on the island that requires real estate development, new construction or major renovations to existing structures must be approved by the Governor's Office, that is, by agencies operating under the direct supervision of the governor. Exceptions for projects in autonomous municipalities are discussed below.

Perhaps as a result, the regulation of project development and construction activities is highly politicized on the island and susceptible to corruption. Experienced government workers who are knowledgeable about the consultation and permitting process are often transferred to other government offices after a change in administration, replaced in turn by less experienced employees affiliated with the winning political party. Corruption in the permitting process, and the harm it does to the business climate, came up repeatedly in our interviews. Consistent with comments by interviewees, corruption in the permitting process has also received attention in public forums. The president of the Retailers' United Center (Centro Unido de Detallistas) has stated that it is an "open

\footnotetext{
${ }^{28}$ See El Nuevo Día, July 15, 2005, pages 8-9 and July 16, 2005, page 26.
} 
secret" that in the agencies that grant permits, such as ARPE, the Planning Board and the Health Department, among others, "money is passed under the table" to obtain the permits. ${ }^{29}$ In recent years, a number of government officials and employees have been convicted in federal court on corruption-related charges in connection with the permitting process. Examples include the Deputy Chief of Staff to the Governor in the first half of the 1990s and, separately, an executive assistant to the governor in the latter portion of the 1990s. Both accepted regular cash payments from contractors in return for access to government officials and expedited permitting. One official's services also included efforts to encourage other government officials to relax construction requirements. ${ }^{30}$

\subsection{Information Costs in the Permitting Process}

The process for obtaining construction permits and agency endorsements is complex and lacking in transparency. In addition, there is no readily accessible central source for the detailed information required to comply with the wide array of regulations. These features of the permitting process raise the information costs of compliance, increase uncertainty about approval, and add to the potential for unexpected delays and bottlenecks. The nature of the bureaucratic regime compounds informational costs and related problems by undermining the development of an experienced, apolitical workforce in key regulatory agencies.

Larger developers mitigate informational costs by employing permitting specialists. These in-house specialists are drawn from former government workers at the Planning Board or ARPE, engineers who have acquired experience in the permitting process, and formerly independent permit specialists or facilitators (gestores). Developers also retain independent permit specialists who handle the permitting maze for fees that vary according to the specific tasks performed. There is an active market for these independent permitting specialists and facilitators, often working in conjunction with law and accounting firms. ${ }^{31}$ Businesses that lack the scale to efficiently employ an in-house

\footnotetext{
${ }^{29}$ See El Nuevo Día, Marian Díaz, January 5, 2005, p. 70.

${ }^{30}$ See United States Court of Appeals for the First Circuit (2005a). The Court's review of the facts is quite instructive about the business climate surrounding the permitting process and the role of corruption.

${ }^{31}$ As another example of efforts to erect regulatory entry barriers, one segment of this market is currently under attack by the College of Engineers and Surveyors. The College argues that non-engineers should not
} 
permit manager, and that are unwilling to pay the fees commanded by independent permitting specialists, must fall back on their own efforts to comply with regulations and navigate the permitting process. This approach typically involves a great deal of trial and error. Several interviewees mentioned the difficulties that confront entrepreneurs and employees who attempt to deal with the permitting process without specialized assistance.

Interviewees also pointed out that even permit specialists often make mistakes and present inadequate documentation to government agencies. Similarly, some interviewees mentioned that a lack of knowledge and professional responsibility on the part of some permitting specialists is a problem. Because many specialists obtain their initial work experience in only one of the many agencies involved in the permitting process, they are not always cognizant of the procedures and rules followed by other agencies.

\subsection{Coordination Problems and Inefficient Implementation}

Apart from high informational costs, the permitting process is also plagued by inefficient implementation on the part of government agencies and the problem of "too many cooks". Certain stages of the permitting process can require the endorsements of up to nineteen agencies. Each endorsing agency has the power to delay or halt the entire development project, and this is more likely to occur when the project faces opposition on political, commercial or environmental grounds. Renewal of agency endorsements during an ongoing construction project can also be a problem. As a result, developers and contractors face substantial uncertainties. The common practice of requiring administrative and public hearings regarding permitting issues increases the need to rely on attorneys to navigate the process.

Many interviewees described the government agencies involved in the permitting process as inefficient. This segment of the government bureaucracy is faulted for excessive complexities, a shortage of personnel and resources, and inadequate employee supervision. Communications with ARPE employees require excessive on-site visits for

be allowed to function as permit gestores, i.e., facilitators. Non-engineers who act as facilitators respond that they work on permitting issues, not engineering issues. 
reasons as mundane as the fact that phone calls often go unanswered. One of us experienced the phone problem first hand on many occasions. On one occasion, several efforts to contact ARPE by phone resulted in two calls that were answered and referrals to several extension numbers of engineers who evaluate projects. However, none of these extensions yielded a response and the effort to acquire information ended unsuccessfully after half an hour of frustration. Similar communication problems were mentioned by interviewees, who noted that it is often more efficient to obtain information in person at the agency rather than by phone or from agency web pages.

\subsection{Autonomous Municipalities}

The Autonomous Municipalities Law (Law No. 81 of August 30, 1991) allows a municipality to bypass the Planning Board and ARPE for construction and development projects confined to its boundaries. To do so, the municipality must meet certain financial standards, be able to manage its own accounting system, have an approved territorial organization plan, and meet other conditions. The municipality can then take over a number of responsibilities from the central government, including management of the permitting process and enforcement of zoning regulations. Although the Autonomous Municipalities Law has been in effect for fourteen years, only six municipalities have achieved autonomous status as of June 2005, and only 24 of 78 municipalities have an approved territorial organization plan. Fiscal limitations and human resource constraints apparently account for the inability or unwillingness of many municipalities to seek autonomous status.

The six autonomous municipalities are Bayamón, Caguas, Carolina, Cidra, Guaynabo, and Ponce. An informal performance ranking (emerging from interviews) suggests that the permitting process functions more smoothly under the autonomous municipalities. Among autonomous municipalities, Ponce is generally praised for efficiency and speediness and is reportedly the only municipality that has fully and efficiently implemented the permitting process. Bayamón and Guaynabo are also classed as efficient, followed by Caguas and Carolina. Interviewees had little experience with Cidra. At the bottom, generally described as far less efficient than the autonomous 
municipalities, is the central government (ARPE). Nevertheless, interviewees did not react positively to the idea of a decentralization of ARPE.

The experience thus far indicates that a few municipalities can manage the permitting process more efficiently than the central government. However, the approach provided by the Autonomous Municipalities Law offers at best a partial solution to problems in the permitting process. Fiscal problems at the municipal level have hampered the process of becoming autonomous, and only two municipalities, Cidra and Guaynabo, became autonomous between 1999 and 2005. Over time, many public services have been transferred from the central government to the municipal level, but there has not been a corresponding increase in municipal financial resources. In fact, as we discussed in Section 3, certain tax incentives enacted into law have cut the flow of revenues to municipalities. In addition, as mentioned by several interviewees, many municipalities lack the scale, infrastructure and human resources to efficiently oversee the permitting process.

\subsection{Other Public Policy Responses}

In addition to the Autonomous Municipalities Law, there have been several other government initiatives to streamline or otherwise improve the permitting process. The government's Express Center for Procedures (Centro Expreso de Trámite, CET) began

operations in 2002. The CET follows an earlier One-Stop Procedure established in 1998 (Law No. 264 of September 4, 1998). In principle, the CET offers concurrent project evaluations by nine agencies, including ARPE, and consideration of environmental issues. While the CET mechanism is helpful, it does not greatly simplify the permitting process, in large part because the CET lacks authority to grant permits. Instead, it functions as a messenger service to other agencies. The proponent submits basic information about its project over the Internet, and then visits the CET with required documents. The CET process reduces paperwork, but filing requirements remain burdensome. For instance, consider projects that require a location consultation (consulta de ubicación) with the Planning Board. By obtaining agency endorsements and comments through the Center, the proponent need file only ten copies of certain documents instead 
of nineteen. Otherwise filing requirements are the same. Most important, the CET takes the regulations as given and cannot issue permits on its own authority.

In an effort to promote ethical conduct and control the operation of the agency, the government created the ARPE Governmental Ethics Committee and the Internal Auditing Office of ARPE in 2000. Other efforts to streamline the permitting process include a recent reform of the Puerto Rico Environmental Public Policy Act. Prior to the reform, the Planning Board issued its own environmental evaluation of proposed construction and development projects, duplicating the efforts of other government agencies and increasing paperwork burdens, filing requirements and government costs. Effective March 2005, the reform delegates the environmental assessment to other government agencies, eliminating the redundant assessment by the Planning Board. This reform streamlines the permitting process somewhat, but it merely eliminates one of the many bureaucratic steps concerning the Planning Board location and approval process sketched above.

Despite awareness that many elements of the permitting process are counterproductive, restrictive regulations continue to proliferate. For example, Law 270 of September 14, 2004, amends the Regulations and Permits Law to require a favorable report, through a certification issued by the Puerto Rico Tourism Company, before approving a construction permit for a hotel, parador, or other project of tourist interest. This amendment, ostensibly designed to ensure the quality of tourist-oriented facilities, adds one more hurdle in an already burdensome permitting process.

\section{Summary and Concluding Remarks}

Puerto Rico has struggled with an employment shortfall of stunning dimensions. The employment rate among working-age persons stood at nearly 50 percent in the early 1950s, then declined over the rest of the decade and again after 1971 to reach levels below 35 percent in the early 1980s. In the past thirty years, Puerto Rican employment rates range from 55 to 65 percent of U.S. rates. This enormous shortfall holds for men and women, cuts across all education groups, and is deeper for persons without a college degree - about four-fifths of Puerto Rico's working-age population. 
To help shed light on the reasons for Puerto Rico's persistently low rate of employment, we investigated several aspects of its employment structure. In this regard, two results stand out. First, the employment shortfall is concentrated in the private sector, particularly the free enterprise segment comprised of businesses that operate in the formal economy without large subsidies, special regulatory advantages, or heavy-handed oversight by government bureaucracies. Even by rather relaxed criteria, less than one quarter of working-age Puerto Ricans hold a job in the free enterprise segment of the economy. By the same criteria, more than half hold free enterprise jobs in the United States. The strikingly underdeveloped state of the private sector supports the view that Puerto Rico suffers from an inhospitable business climate.

Second, Puerto Rico's industry structure has for decades been grossly misaligned with the human capital mix of its population. The average schooling level of working-age persons in Puerto Rico is, and remains, below that of any state. Yet, in terms of the schooling intensity of its industry structure, Puerto Rico ranks among the top third of U.S. states. Put differently, the missing jobs in Puerto Rico are concentrated in laborintensive industries that rely heavily on less-educated workers. For example, Puerto Rico's employment rate in Eating, Drinking and Lodging is lower than the rate for any state in recent decades and less than one-third the rate in Hawaii. The persistent inability of the Puerto Rican economy to generate jobs that fit the human capital mix of its population testifies to a profound failure of industrial and employment policy.

The evidence does not support the view that more schooling can, by itself, resolve Puerto Rico's employment problems. Very large gains in schooling attainment in recent decades have accompanied very modest employment gains. Relative to the United States, Puerto Rico's employment shortfall exceeds ten percent of the population for college-educated persons and twenty percent or more for groups with less education. Thus, if and when Puerto Rico matches U.S. schooling levels, very large employment shortfalls will persist in the absence of deep reforms.

No single policy or institutional deficiency fully accounts for Puerto Rico’s huge employment shortfall, underdeveloped private sector, and misaligned industry structure. Indeed, the list of significant contributing factors is long and varied: 
- Large government transfer payments undermine work incentives and contribute to a deficit of work experience and marketable skills.

- Minimum wage laws discourage the hiring of less skilled workers, suppress the growth of employment in industries and activities that rely heavily on less educated workers, and diminish opportunities to acquire experience and training on the job.

- Historically, the large role for public sector employment and production in Puerto Rico has softened competitive pressures on the island and discouraged the emergence of a vibrant private sector.

- Section 936 of the U.S. tax code and other federal tax incentives have helped create an industry structure in Puerto Rico that is poorly aligned with the type of job opportunities needed by its population. At best, Section 936 provided for a modest number of jobs in Puerto Rico at enormous cost to the U.S. treasury.

- Puerto Rico's own tax code is replete with provisions that benefit special business interests at the expense of the general welfare. These tax code provisions both reflect and contribute to a business climate in which profitability and survival too often rest on the ability to obtain favors from the government, rather than the ability to innovate, raise productivity, and serve consumers.

- Puerto Rico's regulatory environment deters business entry, hampers job creation and erodes competitive pressures in many ways. Occupational licensing requirements create artificial entry barriers, restricting the supply of services and raising prices to consumers. Government oversight of business entry and location decisions raises entry costs and affords commercial rivals the opportunity to block entry. "Buy local" laws insulate business interests from foreign competition and raise prices for consumers. Like many provisions of the tax code, these aspects of the regulatory environment serve special business interests at the expense of the general welfare. They reflect and promote a business culture focused on rent seeking. 
- The permitting process - whereby the government oversees construction and real estate development projects, the commercial use of equipment and facilities, and the periodic renewal of various business licenses - suffers from several serious problems. These problems raise the costs of doing business, undercut the drive for employment growth, and retard economic development. As part of our study, we interviewed more than one hundred persons who have expertise on or first-hand experience with the permitting process. Among the interviewees, there are widely shared views that the permitting process is excessively slow and costly, fraught with uncertainty, subject to capricious outcomes, prone to corruption, and susceptible to manipulation by business rivals, politicians and special interest groups. Independent evidence from public sources supports these claims.

Efforts to reform the permitting process have met with very limited success. A partial exception is the Autonomous Municipalities Law of 1991 that allows municipal governments to take over much of the permitting process from the Governor's Office, if the municipality meets several conditions. Many interviewees stated that the permitting process functions much more smoothly in a handful of autonomous municipalities. Fourteen years after the Law's enactment, however, only six municipalities have achieved autonomous status. For reasons of insufficient scale, limited financial resources and lack of personnel, it is doubtful whether the other 72 municipalities can efficiently manage the permitting process, at least in its current form.

Our study emphasizes employment outcomes, but the policies and institutional arrangements we consider also lower real incomes and living standards by undermining productivity. Transfer payments and minimum wage laws lower worker productivity by contributing to a deficit of work experience. Special-interest tax subsidies distort market price signals that would otherwise guide capital and labor to their best uses, lowering productivity in the process. Inefficiencies in the permitting process raise the cost of doing business, lowering productivity directly. Regulatory entry barriers, "buy local" laws, and a large role for the public sector soften competitive pressures on the island. In turn, softer competition weakens the pressure to innovate and provide value for customers. Artificial entry barriers and inefficiencies in the permitting process also retard the type of creative destruction process that transformed the U.S. retail sector in recent decades, bringing 
dramatic productivity gains for businesses and lower prices and wider product selections for consumers. Finally, institutional arrangements that foster rent-seek behavior lower productivity, because they encourage socially wasteful efforts to curry favor with government officials and secure preferential treatments, rather than socially productive efforts to better serve customers, improve products and expand markets. 


\section{References}

Alesina, Alberto and Edward L.Glaeser. 2004. Fighting Poverty in the U.S. and Europe: A World of Difference. Oxford University Press.

Alm, James and Ramon Cao Garcia. 2005. "Fiscal Policies in Puerto Rico." Georgia State University and the University of Puerto Rico. Forthcoming in Economic Growth in Puerto Rico, edited by Barry Bosworth, Susan Collins and Miguel A. Soto.

Basker, Emek. 2005a. "Job Creation or Destruction?: Labor-Market Effects of Wal-Mart Expansion." Review of Economics and Statistics, 87, no. 1, 174-183.

Basker, Emek. 2005b. "Selling a Cheaper Mousetrap: Wal-Mart's Effect on Retail Prices." University of Missouri, March.

Becker, Gary S. 1993. Human Capital: A Theoretical and Empirical Analysis with Special Reference to Education, third edition. The University of Chicago Press.

Bosworth, Barry and Susan M. Collins. 2005. "Economic Growth in Puerto Rico." The Brookings Institution. Forthcoming in Economic Growth in Puerto Rico, edited by Barry Bosworth, Susan Collins and Miguel A. Sot

Burtless, Gary and Orlando Sotomayor. 2005. "Effect of Public Transfers on Puerto Rican Labor Supply." The Brookings Institution and the University of Puerto Rico. Forthcoming in Economic Growth in Puerto Rico, edited by Barry Bosworth, Susan Collins and Miguel A. Soto.

Cao García, Ramón J. 2004. Impuestos en Puerto Rico: Treinta Años de Experiencias y Estudios. San Juan: Grupo Editorial Akron.

Carlton, Dennis W. and Jeffrey M. Perloff. 2000. Modern Industrial Organization, third edition. Reading, Massachusetts: Addison-Wesley.

Castillo-Freeman Alida, and Richard Freeman. 1992. "When the Minimum Wage Really Bites: The Effect of the U.S.-Level Minimum on Puerto Rico." In Immigration and the Work Force, edited by George Borjas and Richard Freeman. University of Chicago Press.

Corneo, Giacomo and Hans Peter Gruener. 2002. "Individual Preferences for Political Redistribution.” Journal of Public Economics 83, no. 1 (January): 83-107.

Davis, Steven J. and Magnus Henrekson. 2005a. "Tax Effects on Work Activity, Industry Mix and Shadow Economy Size: Evidence from Rich-Country Comparisons." In Labour Supply and the Incentives to Work in Europe, edited by R. Gomez Salvador et al. Edward Elgar Press. 
Davis, Steven J. and Magnus Hernrekson. 2005b. "Wage-Setting Institutions as Industrial Policy." Labour Economics 12, no. 3 (June): 345-377.

Díaz, Mirian. 2005. “Ideas Del Sector Privado al Cogobierno.” El Nuevo Día (January 5): 70.

Djankov, Simeon, Rafael La Porta, Florencio Lopez de Silanes and Andrei Schleifer (2002). The Regulation of Entry." Quarterly Journal of Economics 117(1): 1-37.

Dunn, Thomas A. and Douglas J. Holtz-Eakin. 2000. "Financial Capital, Human Capital, and the Transition to Self-Employment: Evidence from Intergenerational Links." Journal of Labor Economics 18, 2: 282-205.

Enchautegui, Maria E. and Richard B. Freeman. 2005. "Why Don't More Puerto Rican Men Work? The Rich Uncle (Sam) Hypothesis." Presented at a conference on the Puerto Rican economy sponsored by the Center for the New Economy and the Brookings Institution in San Juan, Puerto Rico, May 10-11, 2005. Forthcoming in Economic Growth in Puerto Rico, edited by Barry Bosworth, Susan Collins and Miguel A. Soto.

Eslava, Marcela, John Haltiwanger, Adriana Kugler and Maurice Kugler. 2004. "The Effect of Structural Reforms on Productivity and Profitability Enhancing Reallocation: Evidence from Columbia." Journal of Development Economics (December): 333-371.

Estudios Técnicos. 2004. La Economía Informal en Puerto Rico, vols. 1-3, prepared for the Puerto Rico Department of Labor and Human Resources.

Fairlie, Robert W. and Alicia Robb. 2003. "Families, Human Capital, and Small Business: Evidence from the Characteristics of Business Owners Survey." Yale University Economic Growth Center Discussion Paper No. 871.

Foster, Lucia, John Haltiwanger and C.J. Krizan. 2004. "Market Selection, Reallocation and Restructuring in the U.S. Retail Trade Sector in the 1990s." Working paper, U.S. Bureau of the Census.

Galdon-Sanchez, Jose E. and James A. Schmitz, Jr. 2002. "Competitive Pressure and Labor Productivity: World Iron Ore Markets in the 1980s." American Economic Review 92 (September): 1222-1235.

Gonzáles, Joanisabel. 2005. "La Abultada Agenda del Comisionado.” El Nuevo Día (January 5): 70 .

Hashimoto, Mansori 1982. "Minimum Wage Effects on Training on the Job." American Economic Review 72, no. 5 (December): 1070-1087.

Hausman, Jerry and Ephraim Leibtag. 2004. "CPI Bias from Supercenters: Does the BLS Know that Wal-Mart Exists?” NBER Working Papers No. 10712. 
Hexner, J. Tomas and Glenn Jenkins. 1998. Puerto Rico: The Economic and Fiscal Dimensions. Citizens Educational Foundation at www.puertorico-herald.org/issues/vol2n03/hexnerjenkins.shtml.

Holmes, Thomas J. 2005. "The Diffusion of Wal-Mart and Economies of Density." Preliminary draft presented at the NBER Summer Institute in Cambridge, Massachusetts, July 2005.

Holmes, Thomas J. and James A. Schmitz, Jr. 2001. "Competition at Work: Railroads vs. Monopoly in the U.S. Shipping Industry." Federal Reserve Bank of Minneapolis Quarterly Review 25, no. 2 (Spring): 3-29.

Hout, Michael and Harvey S. Rosen. 2000. "Self-Employment, Family Background, and Race." Journal of Human Resources 35 (Fall): 670-692.

Hunter, Lawrence A. 2003. "Leave No State or Territory Behind: Formulating a Pro-Growth Economic Strategy for Puerto Rico.” Institute for Policy Innovation (IPI) Policy Report no. 117 (August).

Jacobson, Louis, Robert J. LaLonde and Daniel G. Sullivan. 1993. "Earnings Losses of Displaced Workers." American Economic Review 83, no. 4 (September): 685-709.

Krueger, Alan. 1995. "The Effect of the Minimum Wage When It Really Bites: A Rexamination of the Evidence from Puerto Rico." Research in Labor Economics 14: 122.

Ladd, Helen F. and Francisco L. Rivera-Batiz. 2005. "Education and Economic Development in Puerto Rico. Presented at a conference on the Puerto Rican economy sponsored by the Center for the New Economy and the Brookings Institution in San Juan, Puerto Rico, May 10-11, 2005. Forthcoming in Economic Growth in Puerto Rico, edited by Barry Bosworth, Susan Collins and Miguel A. Soto.

Lawrence, Robert Z. and Juan Lara. 2005. "Puerto Rico: Trade Performance and Industrial Policy." Presented at a conference on the Puerto Rican economy sponsored by the Center for the New Economy and the Brookings Institution in San Juan, Puerto Rico, May 1011, 2005. Forthcoming in Economic Growth in Puerto Rico, edited by Barry Bosworth, Susan Collins and Miguel A. Soto.

Markiewicz, Kira, Nancy Rose and Catherine Wolfram. 2004. "Does Competition Reduce Costs? Assessing the Impact of Regulatory Restructuring on U.S. Electric Generation Efficiency." NBER Working Paper No. 11001.

McKinsey Global Institute. 2001. U.S. Productivity Growth, 1995-2000. Washington, D.C.: McKinsey Global Institute.

Mincer, Jacob. 1962. "On-the-Job Training: Costs, Returns, and Some Implications," Journal of Political Economy 70, no. 5, Part 2 (October): 50-79. 
Mincer, Jacob. 1984. “The Economics of Wage Floors.” Research in Labor Economics 6: 311333.

Nakamura, Leonard. 1999. "The Measurement of Retail Output and the Retail Revolution." Canadian Journal of Economics, 32, no. 2 (April), 408-425

Neal, Derek. 1995. "Industry-Specific Human Capital: Evidence from Displaced Workers." Journal of Labor Economics 13 (October): 653-677.

Neumark, David and Olena Nizalova. 2004. "Minimum Wage Effects in the Longer Run." NBER Working Paper No. 10656.

Odishelidze, Alexander and Arthur Laffer. 2004. Pay to the Order of Puerto Rico: The Cost of Dependence to the American Taxpayer. Allegiance Press.

Parent, Daniel. 2000. "Industry-Specific Capital and the Wage Profile: Evidence from the National Longitudinal Survey of Youth and the Panel Study of Income Dynamics." Journal of Labor Economics 18: 306-321.

Pelzman, Joseph. 2002. "Imported Capital Dependency as an Economic Development Strategy: The Failure of Distortionary Tax Policies in Puerto Rico." George Washington University, European Research Center, Occasional Paper No. 50.

Reynolds, Lloyd and Peter Gregory. 1965. Wages, Productivity, and Industrialization in Puerto Rico. Richard Irwin, Inc.

Rivera-Batiz, Francisco L. and Carlos E. Santiago. 1996. Island Paradox: Puerto Rico in the 1990s. Russell Sage Foundation.

Rodríguez Santiago, Elizabeth (2005). "Los Arbitrios sobre la Cerveza y el Ron en Puerto Rico y la Obligación del Trato Nacional del GATT: Comparación con la Jurisprudencia de la OMC sobre Impuestos a las Bebidas Alcohólicas.” Working Paper No. 1, Center for Business Research and Academic Initiatives, Faculty of Business Administration, University of Puerto Rico-Río Piedras, March.

Santiago, Carlos. 1989. “The Dynamics of Minimum Wage Policy in Economic Development: A Multiple Time-Series Approach. Economic Development and Cultural Change 38, no. 1 (October): 1-30.

Schmitz, James A., Jr., and Arilton Teixeira. 2004. "Privatization's Impact on Private Productivity: The Case of Brazilian Iron Ore." Federal Reserve Bank of Minneapolis Research Department Staff Report 337. 
Schmitz, James A., Jr. 2005. "What Determines Productivity? Lessons from the Dramatic Recovery of the U.S. and Canadian Iron Ore Industries Following their Early 1980s Crisis." Journal of Political Economy 113: 582-624.

Sieling, Mark, Brian Friedman and Mark Dumas. 2001. "Labor Productivity in the Retail Trade Industry, 1987-99.” Monthly Labor Review, December, 3-14.

Sivadasan, Jagadeesh. 2003. "Barriers to Entry and Productivity: Micro-Evidence from Indian Manufacturing Sector Reforms." University of Chicago Graduate School of Business.

Smith, Adam. 1976. An Inquiry into the Nature and Causes of the Wealth of Nations. Edited by Edwin Cannan, with a preface by George J. Stigler. Chicago, Illinois: University of Chicago Press.

Solá, Ricardo. 2004. “La Necesidad de Simplificar la Compleja Relación entre los Procesos Ambientales, de Planificacion, Consultas, Endosos y Permisos," Columna Vol 2 (4): 1417.

Syverson, Chad. 2004. "Market Structure and Productivity: A Concrete Example." Journal of Political Economy 112: 1881-1222.

U.S. Bureau of the Census. 2005. Statistical Abstract of the United States, $12^{\text {th }}$ edition. U.S. Government Printing Office.

United States Court of Appeals for the First Circuit. 2005a. United States v. María de la Angeles Rivera-Rangel. Appeal from the U.S. District Court for the District of Puerto Rico, Opinion No. 03-2544, February 8.

United States Court of Appeals for the First Circuit. 2005b. Walgreen Co., Walgreen of San Patricio, and Walgreen of Puerto Rico v. John V. Rullan, Secretary of the Puerto Rico Health Department. Appeal from the U.S. District Court for the District of Puerto Rico, Opinion No. 03-2542, April 22.

U.S. General Accounting Office. 1993. "Tax Policy: Puerto Rico and the Section 936 Tax Credit," Report to the Chairman, Committee on Finance, U.S. Senate (June).

World Bank. 2004. Doing Business in 2005: Removing Obstacles to Growth. Washington, D.C.: The World Bank and Oxford University Press. 
Table 1. Employment Rates in Puerto Rico Compared to the U.S. Mainland

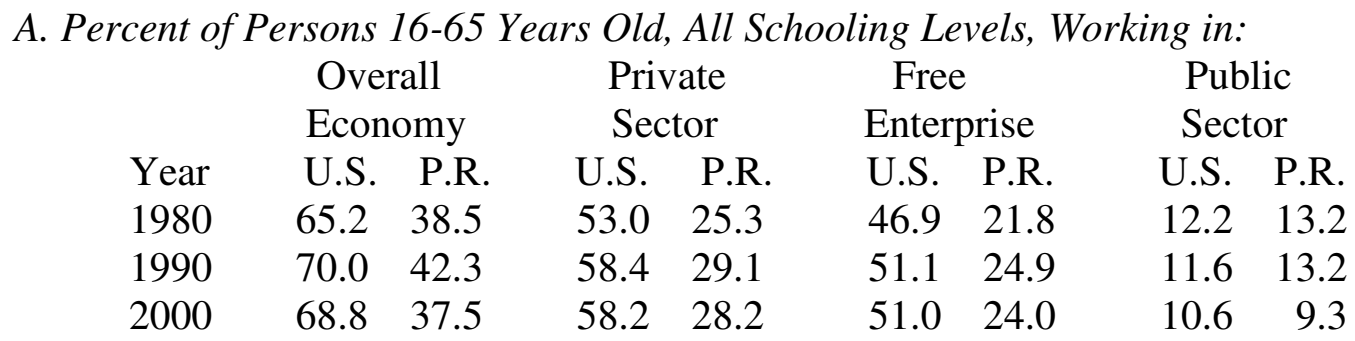

\begin{tabular}{ccccccccc} 
B. Percent of Persons 16-65 Years Old with & \multicolumn{4}{c}{ 14 Years of Schooling Working in: } \\
\multicolumn{4}{c}{ Overall } & \multicolumn{2}{c}{ Private } & \multicolumn{2}{c}{ Free } & \multicolumn{2}{c}{ Public } \\
& \multicolumn{1}{c}{ Economy } & \multicolumn{2}{c}{ Sector } & Enterprise & \multicolumn{2}{c}{ Sector } \\
Year & U.S. & P.R. & U.S. & P.R. & U.S. & P.R. & U.S. & P.R. \\
1980 & 78.8 & 66.1 & 56.8 & 33.8 & 49.6 & 28.7 & 21.9 & 32.3 \\
1990 & 84.5 & 70.6 & 64.0 & 39.6 & 55.4 & 33.3 & 20.5 & 31.0 \\
2000 & 82.5 & 61.6 & 63.9 & 40.7 & 56.8 & 35.9 & 18.6 & 20.9
\end{tabular}

C. Percent of Persons 16-65 Years Old with 16+ Years of Schooling Working in:

\begin{tabular}{cccccccccc} 
& \multicolumn{2}{c}{ Overall } & \multicolumn{2}{c}{ Private } & \multicolumn{2}{c}{ Free } & \multicolumn{2}{c}{ Public } \\
& \multicolumn{2}{c}{ Economy } & \multicolumn{2}{c}{ Sector } & \multicolumn{2}{c}{ Enterprise } & \multicolumn{2}{c}{ Sector } \\
Year & U.S. & P.R. & U.S. & P.R. & U.S. & P.R. & U.S. & P.R. \\
1980 & 83.4 & 76.8 & 55.5 & 34.1 & 47.9 & 27.5 & 27.9 & 42.6 \\
1990 & 85.5 & 75.2 & 62.7 & 39.8 & 53.6 & 32.6 & 22.8 & 35.4 \\
2000 & 83.3 & 65.5 & 63.1 & 41.3 & 55.7 & 35.5 & 20.2 & 24.2
\end{tabular}

Notes: The Public Sector includes all employees of federal and sub-federal governments, and the Private Sector encompasses the rest of the economy. The Free Enterprise segment of the Private Sector excludes non-governmental employees in Public Utilities and Sanitary Services, Primary and Secondary Education, Colleges and Universities, Construction and several small industries for which public sector employment exceeds 35 percent of industry employment in Puerto Rico. In 1990, these industries are Museums, Galleries and Zoos; Business, Trade and Vocational Schools; Bus Service and Urban Transit; Research, Development and Testing; Social Services, n.e.c.; Forestry, and Libraries. (The foregoing list is only a subset of industries with public sector employment shares greater than 35\% in Puerto Rico.) The definition of the Free Enterprise segment uses a nearly identical set of excluded industries in 1980 and a slightly narrower set in 2000. Unpaid family workers are not counted among the employed.

Source: Authors' calculations on household census data for 1980, 1990 and 2000 
Table 2. Market Work Activity by Schooling Levels in Puerto Rico Compared to the United States, Men, $16-65$ Years of Age

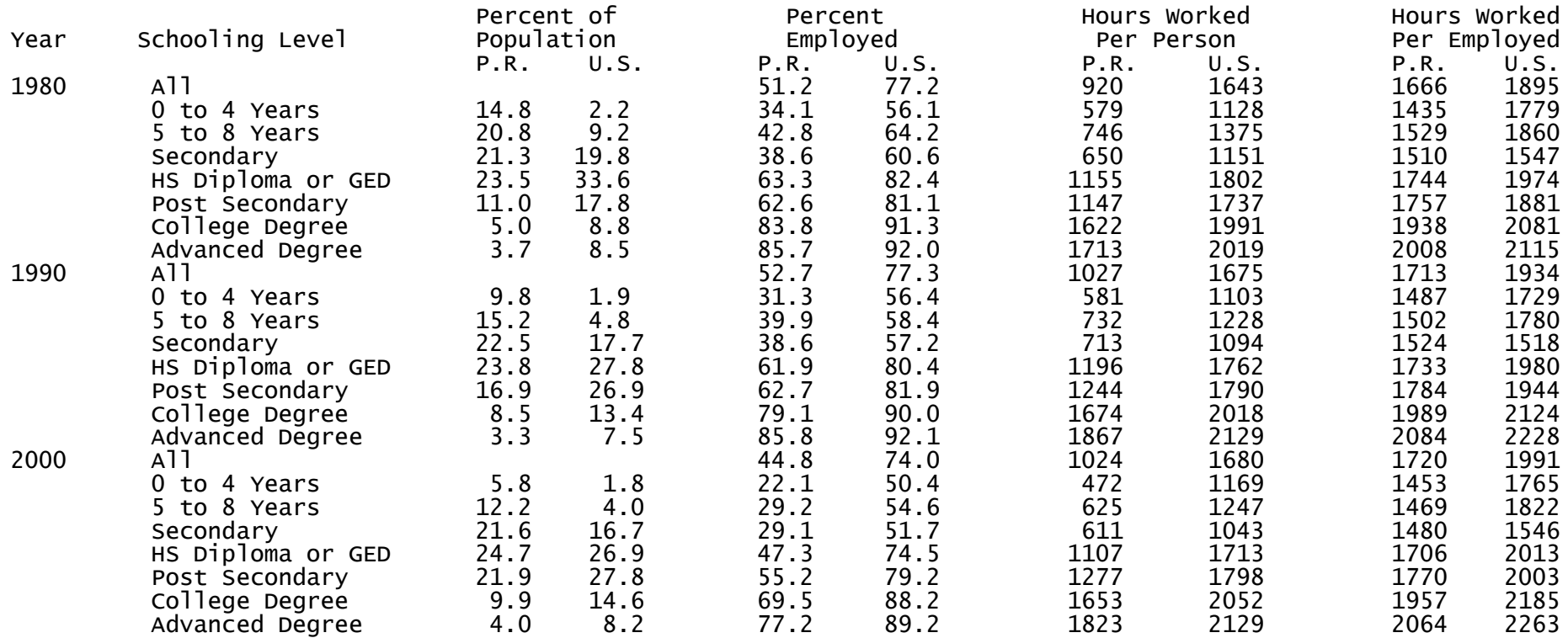

Notes: Percent Employed refers to the percentage of persons with a job in the reference week. The hours worked figures refer to the previous calendar year. They are calculated as the product of weeks worked times usual hours of work per week. There are differences across Census years in the coding of educational attainment, but these differences are modest for the schooling categories reported in the table.

Source: Authors' calculations on household census data for 1980, 1990 and 2000 . 
Table 3. Market Work Activity by Schooling Levels in Puerto Rico Compared to the United States, Women, 16-65 Years of Age

\begin{tabular}{|c|c|c|c|c|c|c|c|c|c|}
\hline Year & Schooling Level & $\begin{array}{l}\text { Perc } \\
\text { Popl }\end{array}$ & Eion & $\begin{array}{l}\text { Per } \\
\text { Emp }\end{array}$ & & $\begin{array}{l}\text { Hour } \\
\text { Per }\end{array}$ & $\begin{array}{l}\text { rked } \\
\text { son }\end{array}$ & $\begin{array}{l}\text { Hour } \\
\text { Per }\end{array}$ & $\begin{array}{l}\text { orked } \\
\text { 1oyed }\end{array}$ \\
\hline & & P.R. & U.S. & P.R. & U.S. & P.R. & U.S. & P.R. & U.S. \\
\hline 1980 & A11 & & & 27.1 & 53.7 & 461 & 914 & 1556 & 1428 \\
\hline & $\begin{array}{l}0 \text { to } 4 \text { Years } \\
5 \text { to } 8 \text { Years }\end{array}$ & $\begin{array}{l}15.9 \\
19.5\end{array}$ & $\begin{array}{l}1.8 \\
8.1\end{array}$ & $\begin{array}{r}8.8 \\
14.4\end{array}$ & 29.6 & $\begin{array}{l}142 \\
236\end{array}$ & $\begin{array}{l}495 \\
592\end{array}$ & $\begin{array}{l}1412 \\
1406\end{array}$ & $\begin{array}{l}1412 \\
1432\end{array}$ \\
\hline & Secondary & 19.4 & 20.3 & 14.9 & 39.6 & 234 & 598 & 1299 & 1175 \\
\hline & HS Diploma or GED & 23.7 & 40.2 & 35.9 & 56.8 & 636 & 1004 & 1617 & 1498 \\
\hline & Post Secondary & 13.2 & 17.7 & 43.5 & 62.1 & 743 & 1062 & 1598 & 1419 \\
\hline & College Degree & 6.2 & 7.3 & 68.6 & 68.4 & 1153 & 1143 & 1674 & 1491 \\
\hline 1990 & $\begin{array}{l}\text { Advanced Degree } \\
\text { A1 } 1\end{array}$ & 2.1 & 4.7 & 71.8 & $\begin{array}{l}77.4 \\
62.8\end{array}$ & $\begin{array}{r}1272 \\
600\end{array}$ & 1318 & $\begin{array}{l}1737 \\
1597\end{array}$ & $\begin{array}{l}1562 \\
1553\end{array}$ \\
\hline & 0 to 4 Years & 9.7 & 1.6 & 9.8 & 33.0 & 170 & 585 & 1381 & 1472 \\
\hline & 5 to 8 Years & 13.5 & 4.0 & 15.1 & 34.5 & 263 & 624 & 1406 & 1444 \\
\hline & Secondary & 19.9 & 16.9 & 16.1 & 42.0 & 279 & 662 & 1307 & 1213 \\
\hline & HS Diploma or GED & 22.2 & 31.2 & 34.1 & 62.4 & $\begin{array}{l}621 \\
779\end{array}$ & 1137 & $\begin{array}{l}1565 \\
1568\end{array}$ & 1583 \\
\hline & $\begin{array}{l}\text { Post Secondary } \\
\text { college Degree }\end{array}$ & 11.6 & 12.2 & 69.3 & 77.5 & 1319 & 1421 & 1793 & 1673 \\
\hline & Advanced Degree & 2.8 & 5.2 & 77.4 & 83.8 & 1543 & 1578 & 1857 & 1771 \\
\hline 2000 & A11 & & & & 63.7 & 643 & 1213 & 1563 & 1639 \\
\hline & 0 to 4 Years & 5.0 & 1.5 & 8. & 31.7 & 160 & 631 & 1332 & 1480 \\
\hline & 5 to 8 Years & 10.2 & $\begin{array}{r}3.2 \\
14.7\end{array}$ & 10.1 & 33.5 & 191 & 656 & 1274 & 1474 \\
\hline & $\begin{array}{l}\text { Secondary } \\
\text { HS Diploma or GED }\end{array}$ & $\begin{array}{l}17.8 \\
22.3\end{array}$ & $\begin{array}{l}14.1 \\
27.0\end{array}$ & $\frac{11}{25} \cdot \frac{1}{2}$ & $\begin{array}{l}41.2 \\
61.6\end{array}$ & $\begin{array}{l}214 \\
517\end{array}$ & $\begin{array}{r}662 \\
1194\end{array}$ & $\begin{array}{l}1169 \\
1463\end{array}$ & $\begin{array}{l}1216 \\
1656\end{array}$ \\
\hline & Post Secondary & 25.4 & 31.3 & 38.7 & 70.6 & 808 & 1344 & 1531 & 1643 \\
\hline & Co11ege Degree & 15.3 & 15.1 & 59.7 & 76.5 & 1292 & 1489 & 1740 & 1774 \\
\hline & Advanced Degree & 4.0 & 7.2 & 67.7 & 81.2 & 1454 & 1630 & 1811 & 1866 \\
\hline
\end{tabular}

See notes to previous table.

Source: Authors' calculations on household census data for 1980, 1990 and 2000. 
Table 4. College-Educated Workers in the Private Sector and the Free Enterprise, Segment as a Percentage of Persons 16-65 Years of Age

\begin{tabular}{|c|c|c|c|c|c|c|}
\hline & \multicolumn{3}{|c|}{ Working in the Private Sector } & \multicolumn{3}{c|}{ Working in Free Enterprise } \\
\hline Year & Puerto Rico & United States & Ratio & Puerto Rico & United States & Ratio \\
\hline 1980 & 2.9 & 8.1 & 2.8 & 2.3 & 7.0 & 3.0 \\
\hline 1990 & 5.2 & 10.1 & 1.9 & 4.3 & 8.7 & 2.0 \\
\hline 2000 & 6.9 & 14.2 & 2.1 & 5.9 & 12.6 & 2.1 \\
\hline
\end{tabular}

See the notes to Table 1 for a definition of the Free Enterprise segment of the economy.

Source: Authors' calculations on household census data for 1980, 1990 and 2000. 
Table 5. Public Sector Employment in Puerto Rico Compared to the U.S. Mainland

A. Public Sector Employment Relative to Total Employment

\begin{tabular}{|c|c|c|c|c|c|c|}
\hline & \multicolumn{3}{|c|}{$\begin{array}{c}\text { Government Employment as } \\
\text { Percent of Paid Employment }\end{array}$} & \multirow{2}{*}{$\begin{array}{c}\text { Puerto Rico's } \\
\text { Industry-Level } \\
\text { Industry Mix } \\
\text { Evaluated } \\
\text { Year }\end{array}$} & $\begin{array}{c}\text { Shares for Government } \\
\text { At U.S. Shares } \\
\text { for Government } \\
\text { Employment }\end{array}$ \\
\cline { 2 - 5 } & U.S. Mainland & \multicolumn{2}{|c|}{ Puerto Rico } \\
Total & $\begin{array}{c}\text { Sub- } \\
\text { Federal }\end{array}$ & Total & $\begin{array}{c}\text { Sub- } \\
\text { Federal }\end{array}$ & $\begin{array}{c}\text { Employment Evaluated } \\
\text { At U.S. Industry Mix }\end{array}$ & 26.7 \\
\hline 1980 & 17.3 & 13.2 & 33.9 & 30.1 & 24.2 & 25.9 \\
\hline 1990 & 16.6 & 11.7 & 31.4 & 27.6 & 22.6 & 21.5 \\
\hline 2000 & 15.4 & 11.8 & 24.9 & 21.6 & 19.3 & \multicolumn{2}{c}{} \\
\hline
\end{tabular}

B. Government Employment as a Percent of Paid Employment in Selected Industries

\begin{tabular}{|l|l|l|l|l|l|l|}
\hline & \multicolumn{3}{|c|}{ Puerto Rico } & \multicolumn{3}{c|}{ U.S. Mainland } \\
\hline \multicolumn{1}{|c|}{ Industry } & 1980 & 1990 & 2000 & 1980 & 1990 & 2000 \\
\hline Electric Light and Power & 93 & 79 & 83 & 15 & 13 & 13 \\
\hline Telephone & 62 & 65 & & 1 & 1 & \\
\hline Wired and Other Telecom Carriers & & & 0 & & & 0 \\
\hline Sugar and Confectionary Manufacturing & 55 & 32 & 16 & 1 & 1 & 0 \\
\hline Residential Care w/o Nursing & 83 & 46 & 32 & 30 & 19 & 12 \\
\hline Nursing Facilities & 70 & 39 & 33 & 17 & 10 & 8 \\
\hline Child Day Care & 66 & 55 & 55 & 19 & 8 & 7 \\
\hline Job Training, Vocational Rehabilitation & 80 & 62 & & 38 & 24 & \\
\hline Vocational Rehabilitation & & & 80 & & & 19 \\
\hline Hospitals & 68 & 53 & 32 & 28 & 21 & 15 \\
\hline Museums, Galleries, and Zoos & 63 & 48 & 79 & 37 & 26 & 34 \\
\hline Sanitary Services & 88 & 86 & & 68 & 52 & \\
\hline Waste Management and Remediation & & & 48 & & & 19 \\
\hline Construction & 20 & 13 & 6 & 9 & 7 & 5 \\
\hline
\end{tabular}

Notes: There are 232 Census industry codes in 1980, 243 in 1990, and 264 in 2000. Some industries listed in Panel B are not fully comparable over time because of changes in census industry classifications.

Source: Authors' calculations on household census data for 1980, 1990 and 2000. 
Table 6. Selected Industry Shares, Puerto Rico Compared to the United States, Percent of Employed Persons, 16-65 Years of Age

\begin{tabular}{|c|c|c|c|c|c|c|c|}
\hline Year & Industry Group & $\begin{array}{l}\text { Puerto } \\
\text { Rico }\end{array}$ & $\begin{array}{l}\text { United } \\
\text { States }\end{array}$ & $\begin{array}{l}50 \text { States } \\
\text { Range }\end{array}$ & $\begin{array}{l}\text { State with } \\
\text { Highest }\end{array}$ & \multicolumn{2}{|c|}{ Selected State } \\
\hline 1980 & \multirow{3}{*}{ Construction } & 7.3 & 5.8 & $3.7-9.9$ & Wyoming & Hawaii & 6.4 \\
\hline 1990 & & 7.5 & 6.2 & $4.8-8.8$ & Nevada & Hawaii & 7.0 \\
\hline 2000 & & 8.4 & 6.8 & $5.2-9.4$ & Nevada & Hawaii & 5.6 \\
\hline 1980 & \multirow{3}{*}{$\begin{array}{l}\text { Sugar and } \\
\text { Confectionary } \\
\text { Manufacturing }\end{array}$} & 0.65 & 0.11 & $0-1.14$ & Hawaii & N.Dakota & 0.30 \\
\hline 1990 & & 0.23 & 0.08 & $0-0.60$ & Hawaii & N.Dakota & 0.24 \\
\hline 2000 & & 0.12 & 0.06 & $0-0.43$ & N. Dakota & Hawaii & 0.20 \\
\hline 1980 & \multirow{3}{*}{ Pharmaceuticals } & 2.0 & 0.2 & $0-1.3$ & New Jersey & Indiana & 0.7 \\
\hline 1990 & & 2.8 & 0.2 & $0-1.2$ & New Jersey & Indiana & 0.7 \\
\hline 2000 & & 3.0 & 0.3 & $0-1.5$ & New Jersey & Indiana & 0.6 \\
\hline 1980 & \multirow{3}{*}{$\begin{array}{l}\text { All Other } \\
\text { Manufacturing }\end{array}$} & 17.5 & 22.1 & $5.2-31.9$ & Rhode Island & Hawaii & 5.6 \\
\hline 1990 & & 13.7 & 17.4 & $5.1-25.6$ & N. Carolina & Hawaii & 5.1 \\
\hline 2000 & & 10.6 & 13.8 & $3.0-22.5$ & Indiana & Hawaii & 3.0 \\
\hline 1980 & \multirow{3}{*}{$\begin{array}{l}\text { Utilities and } \\
\text { Sanitary } \\
\text { Services }\end{array}$} & 2.3 & 1.4 & $0.9-2.5$ & Tennessee & Hawaii & 1.0 \\
\hline 1990 & & 2.0 & 1.3 & $0.8-2.4$ & Wyoming & Hawaii & 0.9 \\
\hline 2000 & & 1.8 & 1.2 & $0.9-2.2$ & W. Virginia & Hawaii & 1.1 \\
\hline 1980 & \multirow{3}{*}{$\begin{array}{l}\text { Eating, } \\
\text { Drinking, and } \\
\text { Lodging }\end{array}$} & 3.6 & 5.3 & $3.7-19.5$ & Nevada & Hawaii & 11.4 \\
\hline 1990 & & 3.4 & 5.8 & $4.2-17.4$ & Nevada & Hawaii & 12.6 \\
\hline 2000 & & 5.5 & 6.1 & $4.5-14.1$ & Nevada & Hawaii & 12.7 \\
\hline 1980 & \multirow{3}{*}{$\begin{array}{l}\text { Entertainment } \\
\text { and Recreation } \\
\text { Services }\end{array}$} & 0.7 & 1.1 & $0.5-9.3$ & Nevada & Hawaii & 1.5 \\
\hline 1990 & & 1.0 & 1.4 & $0.6-9.0$ & Nevada & Hawaii & 1.7 \\
\hline 2000 & & 0.9 & 1.7 & $0.9-11.9$ & Nevada & Hawaii & 2.3 \\
\hline 1980 & \multirow{3}{*}{$\begin{array}{l}\text { Elementary and } \\
\text { Secondary } \\
\text { Schooling }\end{array}$} & 8.7 & 5.9 & $4.2-7.8$ & Alaska & Hawaii & 4.5 \\
\hline 1990 & & 7.7 & 5.5 & $3.8-8.2$ & Wyoming & Hawaii & 4.3 \\
\hline 2000 & & 7.2 & 6.0 & $4.2-7.9$ & Wyoming & Hawaii & 5.8 \\
\hline 1980 & \multirow{3}{*}{$\begin{array}{l}\text { Public } \\
\text { Administration }\end{array}$} & 12.5 & 5.2 & $3.5-14.2$ & Maryland & Hawaii & 8.9 \\
\hline 1990 & & 14.0 & 4.8 & $3.2-11.7$ & Maryland & Hawaii & 7.5 \\
\hline 2000 & & 10.7 & 4.8 & $3.3-10.8$ & Alaska & Hawaii & 7.3 \\
\hline
\end{tabular}

Notes: Figures for the United States include the District of Columbia, but the 50 States Range does not. The state-level employment figures reflect the location of the worker's residence, not the location of the job. Thus, for example, Public Administration accounts for a relatively high percentage of Maryland employment, because many Maryland residents commute to government jobs in the District of Columbia.

Source: Authors' calculations on household census data for 1980, 1990 and 2000. 
Table 7. Employees by Establishment Size in Four Major Industry Groups, Puerto Rico Compared to the United States, 1997

\begin{tabular}{ccccc} 
& \multicolumn{4}{c}{ in the Industry Group } \\
$\begin{array}{c}\text { Number of } \\
\text { Employees }\end{array}$ & \multicolumn{3}{c}{ Construction } & \multicolumn{3}{c}{ Manufacturing } \\
at Establishment & States & Puerto & United & Puerto \\
1 to 4 & 13.5 & 2.8 & 1.5 & 0.8 \\
5 to 9 & 13.9 & 5.0 & 2.5 & 1.1 \\
10 to 19 & 15.7 & 7.6 & 4.6 & 3.2 \\
20 to 49 & 20.8 & 15.9 & 10.6 & 7.3 \\
50 to 99 & 13.1 & 18.3 & 11.7 & 7.2 \\
100 to 249 & 12.1 & 24.4 & 20.4 & 16.2 \\
250 to 499 & 5.4 & 13.8 & 16.2 & 23.4 \\
$500+$ & 5.4 & 12.3 & 32.5 & 40.7 \\
& Retail & Trade & Wholesale Trade \\
& United & Puerto & United & Puerto \\
& States & Rico & States & Rico \\
1 & 0.3 & 1.8 & 1.2 & 0.7 \\
2 & 0.7 & 2.6 & 1.7 & 1.3 \\
3 or 4 & 2.1 & 6.2 & 4.2 & 3.3 \\
5 or 6 & 2.6 & 5.5 & 4.4 & 7.5 \\
7 to 9 & 3.6 & 7.3 & 5.9 & 6.4 \\
10 to 14 & 4.2 & 9.0 & 8.5 & 8.8 \\
15 to 19 & 2.6 & 6.7 & 6.7 & 6.6 \\
20 to 49 & 7.6 & 24.5 & 22.4 & 23.8 \\
$50+$ & 76.3 & 36.4 & 44.9 & 41.5
\end{tabular}

Notes: Size distribution statistics are for paid employees, and they exclude unpaid family workers and the proprietors and partners of unincorporated businesses. The size categories above reflect the finest breakdowns available on a consistent basis for both the United States and Puerto Rico in the Economic Census of 1997. The Economic Census does not report measures of economic activity by firm size for Puerto Rico.

Sources: The 1997 Economic Census of Puerto Rico and the Island Areas at http://www.census.gov/csd/ia/p_puerto97.htm, and 1997 Economic Census at http://www.census.gov/epcd/www/econ97.html. The Economic Census of Puerto Rico is not available for a more recent year as of June 2005. 
Table 8. Employees of Unincorporated Enterprises in Four Major Industry Groups, Puerto Rico Compared to the United States, 1997

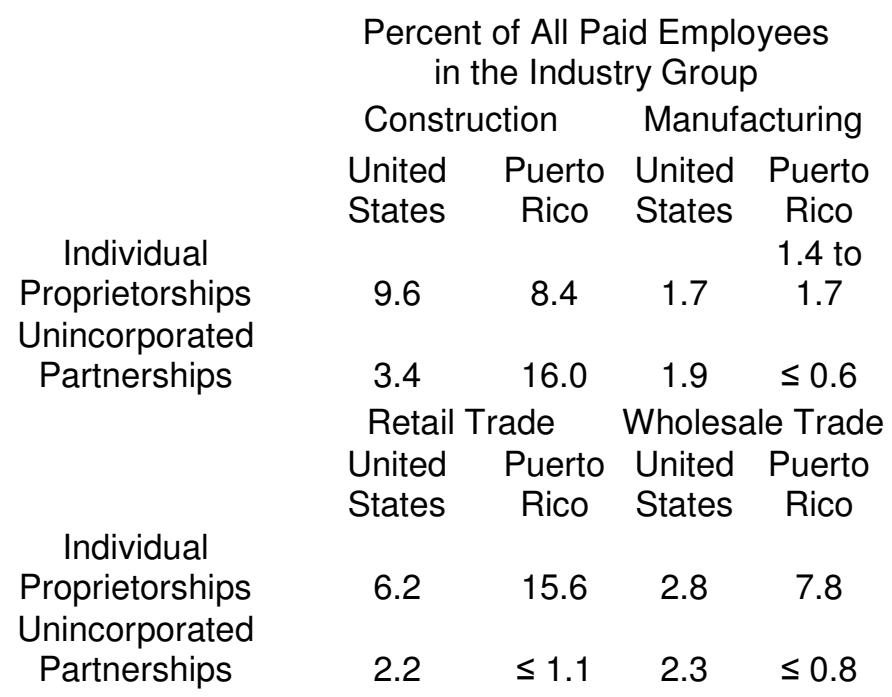

Notes: Statistics are for paid employees, and they exclude unpaid family workers and the proprietors and partners of unincorporated businesses. Certain figures for Puerto Rico are available only within a range.

Sources: The 1997 Economic Census of Puerto Rico and the Island Areas at http://www.census.gov/csd/ia/p_puerto97.htm, and 1997 Economic Census at http://www.census.gov/epcd/www/econ97.html. The Economic Census of Puerto Rico is not available for a more recent year as of June 2005. 
Table 9. World Bank Business Climate Indicators for 2004

(1) Starting a Formal Business

Number of required procedures

Time to complete procedures (days)

Cost to complete procedures, excluding bribes (\% of annual income per capita)

Minimum capital to register business

(\% of annual income per capita)

\begin{tabular}{cccc}
\multicolumn{5}{c}{ Latin } & & \\
Puerto & America \& & & United \\
Rico Caribbean & Chile $\quad$ Islands OECD Ireland Singapore States
\end{tabular}

(2) Hiring and Firing Workers

Difficulty of Hiring Index

Rigidity of Hours Index

Difficulty of Firing Index

Rigidity of Employment Index

Firing costs (weeks of wages)

$\begin{array}{ccccccc}7 & 9 & 11 & 6 & 4 & 7 & 5 \\ 7 & 27 & 70 & 25 & 24 & 8 & 5 \\ 7.0 & 10.0 & 62.8 & 8.0 & 10.3 & 1.2 & 0.6 \\ 1.0 & 0.0 & 28.9 & 44.1 & 0.0 & 0.0 & 0.0 \\ & & & & & & \\ 22.0 & 17.0 & 44.4 & 26.2 & 28.0 & 0 & 0.0 \\ 20.0 & 20.0 & 53.3 & 50.0 & 40.0 & 0 & 0.0 \\ 20.0 & 20.0 & 34.3 & 26.8 & 20.0 & 0 & 10.0 \\ 21.0 & 19.0 & 44.0 & 34.4 & 29.0 & 0 & 3.0 \\ 0.0 & 51.0 & 70.8 & 40.4 & 52.0 & 4 & 8.0\end{array}$

(3) Getting Credit

Cost to create and register collateral

(\% of income per capita)

Legal Rights Index

$0.1 \quad 5.3$

$6.0 \quad 4.0$

19.4

$5.2 \quad 3.2$

0.3

0.1

Credit Information Availability Index

$\begin{array}{ll}5.0 & 6.0\end{array}$

3.8

$6.3 \quad 8.0$

$10.0 \quad 7.0$

Public credit registry coverage

(borrowers per 1000 adults)

Private credit bureau coverage

(borrowers per 1000 adults)

$0.0 \quad 290$

4.7

$5.0 \quad 5.0$

4.0

6.0

(4) Enforcing a Debt Obligation

Number of required procedures

Time to complete procedures (days)

Recovery cost (\% of debt)

\section{(5) Closing an Insolvent Business}

Time required (years)

Cost of insolvency process

(\% of estate value)

$\begin{array}{lllll}85.7 & 76.2 & 0.0 & 0.0 & 0.0\end{array}$

643220

325.1

$577.2 \quad 1000 \quad 335$

1000

Recovery rate (percent)

$\begin{array}{ccccccc}43 & 28 & 35 & 19 & 16 & 23 & 17 \\ 270 & 305 & 462 & 229 & 217 & 69 & 250 \\ 21.0 & 10.4 & 23.3 & 10.8 & 21.1 & 9.0 & 7.5\end{array}$

$\begin{array}{ccccccc}3.8 & 5.6 & 3.7 & 1.7 & 0.4 & 0.8 & 3.0 \\ 8.0 & 18.0 & 15.8 & 6.8 & 8.0 & 1 & 8.0 \\ 61.4 & 19.3 & 26.6 & 72.1 & 88.9 & 91.3 & 68.2\end{array}$

Source: World Bank (2005) and the World Bank Doing Business Database at http://www.doingbusiness.org/Default.aspx (accessed on August 21, 2005).

Notes: The indexes under (2) range from 0 to 100 , with higher values indicating more rigid regulation. The Legal Rights Index ranges from 0 to 10, "with higher scores indicating that collateral and bankruptcy laws are better designed to expand access to credit." The Credit Information Availability Index ranges from 0 to 6, with higher values indicating greater availability. See the source publication for additional information about the indicators and their construction. 
Table 10: Illustrative Business Incentives Enacted into Law by the Puerto Rican Government from August 2001 to August 2002

\section{7-Aug-01}

Law 109 Grants a 50 percent tax credit, under certain conditions, for the acquisition of a business in the process of closing operations in Puerto Rico.

Law 110 Raises the tax credit on the purchase of products manufactured in Puerto Rico by certain enterprises from 10 to 25 percent.

Law 112 Grants certain businesses the option of recognizing a deduction for spending on the purchase or construction of buildings, structures, and equipment and machinery.

Law 113 Grants double deductions for spending on employee training and on research and development.

Law 115 Liberalizes administrative restrictions on credit cooperatives to allow them to act as agents in selling mortgage loans and in launching new products.

Creates the Credit and Guarantees Fund for Agricultural Loans (Fondo de Credito y

Law 117 Guarantias de Prestamos Agricolas). If a farmer cannot meet a loan obligation to a private bank, the farmer can request a grant from the Fund to cover the debt. The Fund is authorized to grant up to $\$ 100$ million during a four-year period.

Creates the Corporation for the Development of the Arts, Sciences, and Film Industry of

Law 121 Puerto Rico. The Corporation offers incentives and administers the funds financing productions.

4-Oct-01

Law 141 Exempts associations of legal owners of vacation clubs from income taxes, promoting the time-share industry.

Law 143 Exempts fees earned by financial institutions for issuing guarantees or letters of credit to finance tourism development projects from income taxes.

Provides tax incentives to innovative technology industries that establish operations in

Law 145 Puerto Rico and that generate high skill scientific, technological, and managerial employment.

3-Dec-01

Law 169 Amends the 1994 Internal Revenue Code to grant eligible businesses a tax credit equal to $10 \%$ of the purchase value for products manufactured in Puerto Rico.

Grants excise tax exemptions to enterprises for the purchase of machinery and equipment

Law 174 to fulfill environmental, security, and health requirements. This law also grants income tax credits on machinery and equipment acquired for businesses devoted to call centers established in Puerto Rico.

14-Dec-01

Permits the Industrial Development Company (Compania de Fomento Industrial) to rent

Law 163 space at low cost to nonprofit organizations for the establishment of factories that employ handicapped workers.

29-Aug-02

Reduces the income tax rate on call center operations to 4 percent or 2 percent, depending

Law 225 on geographic service area. It also grants full exemption from real estate taxes, municipal patents, and other municipal taxes during the first five years afte the law takes effect. Grants full exemption from income taxes and partial exemption on municipal patents and

Law 226 other municipal taxes to certain businesses located in Vieques, Culebra, or any other municipality with similar economic or unemployment situations. 
Figure 1: Employment as a Percent of Persons 16 and Older, 1947 to 2001

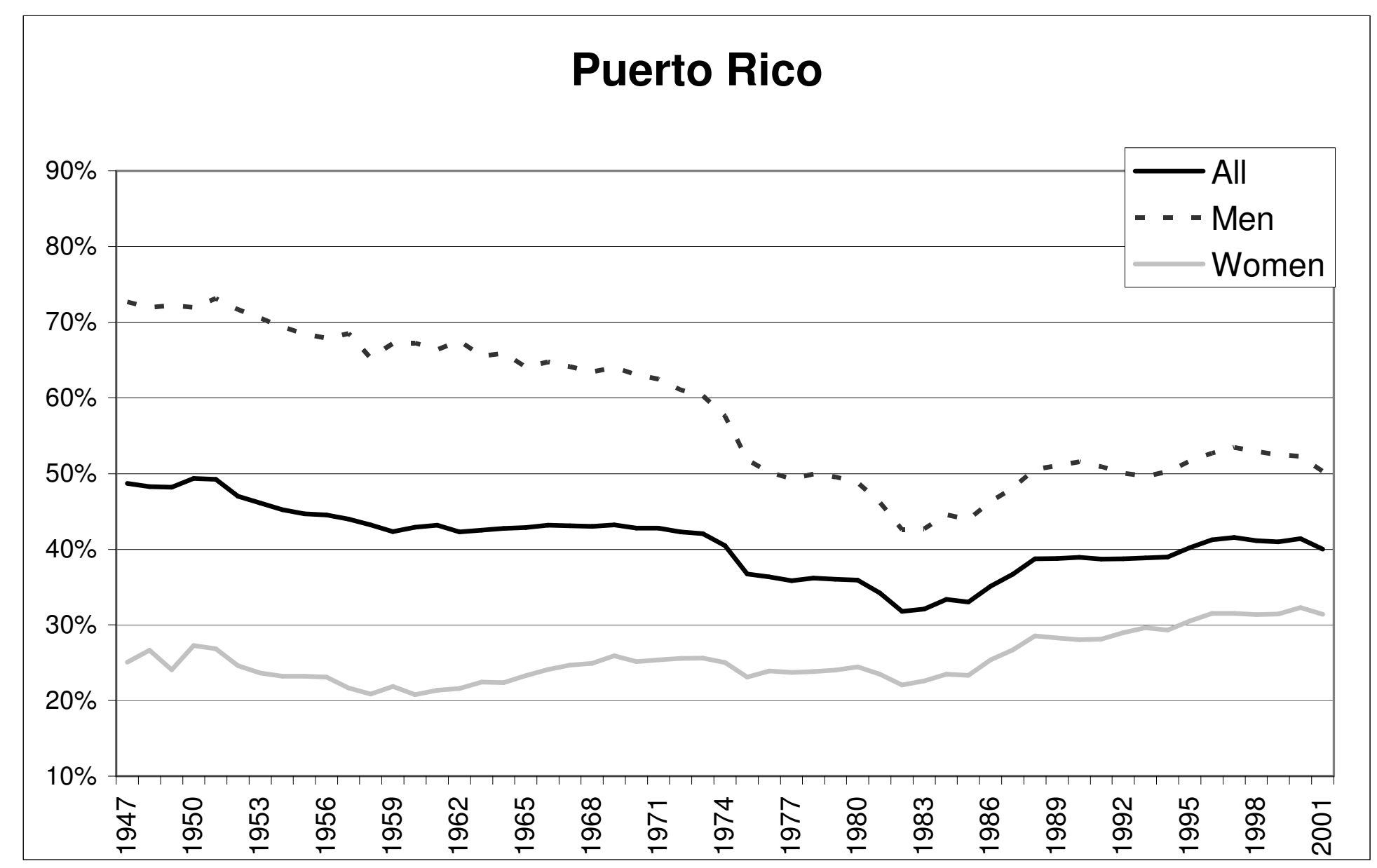


Figure 1 (continued): Employment as a Percent of Persons 16 and Older, 1947 to 2001

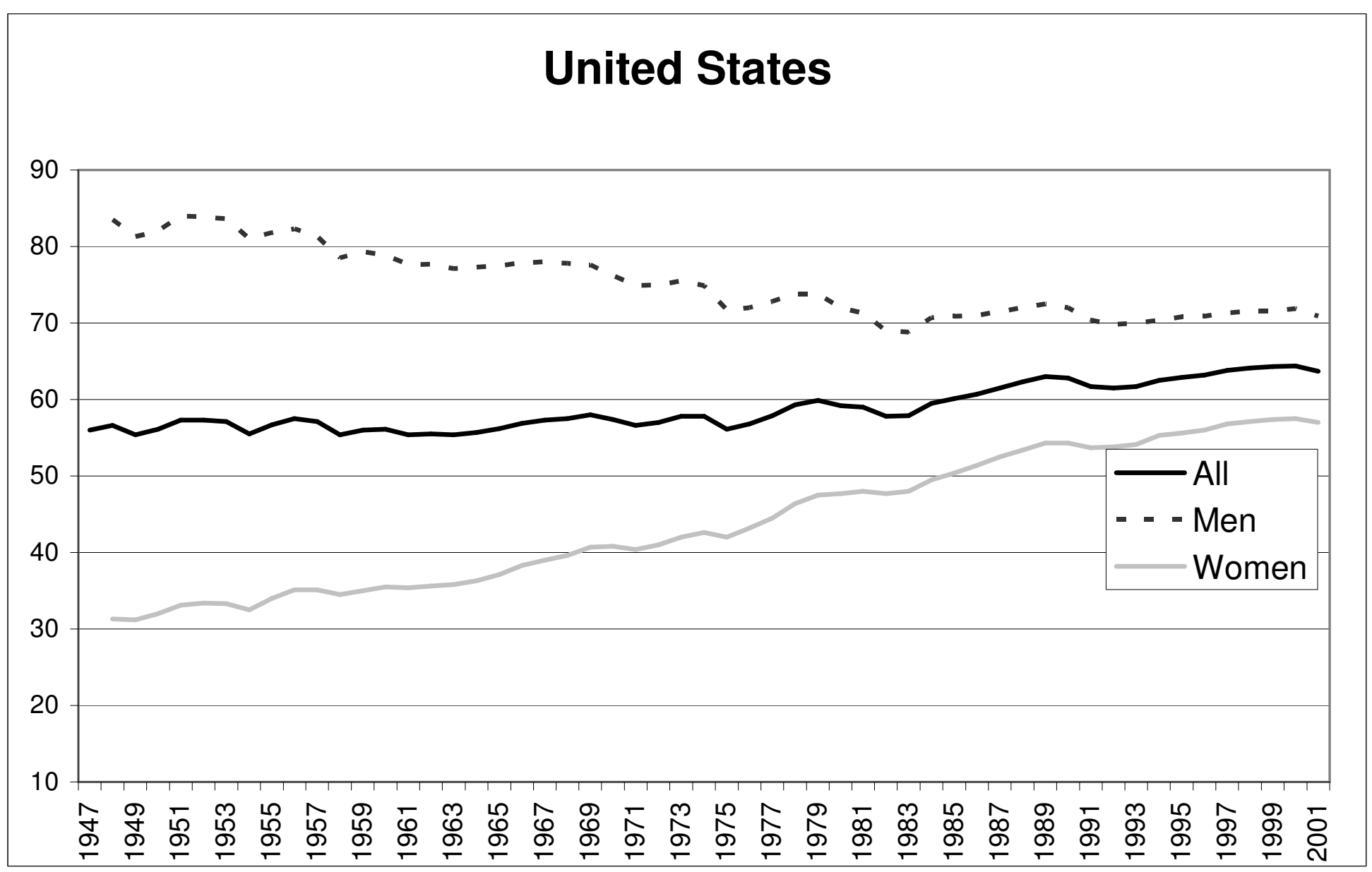


Figure 2. Schooling Intensity of State's Industry Mix Versus Mean Schooling Years of Its Adult Population
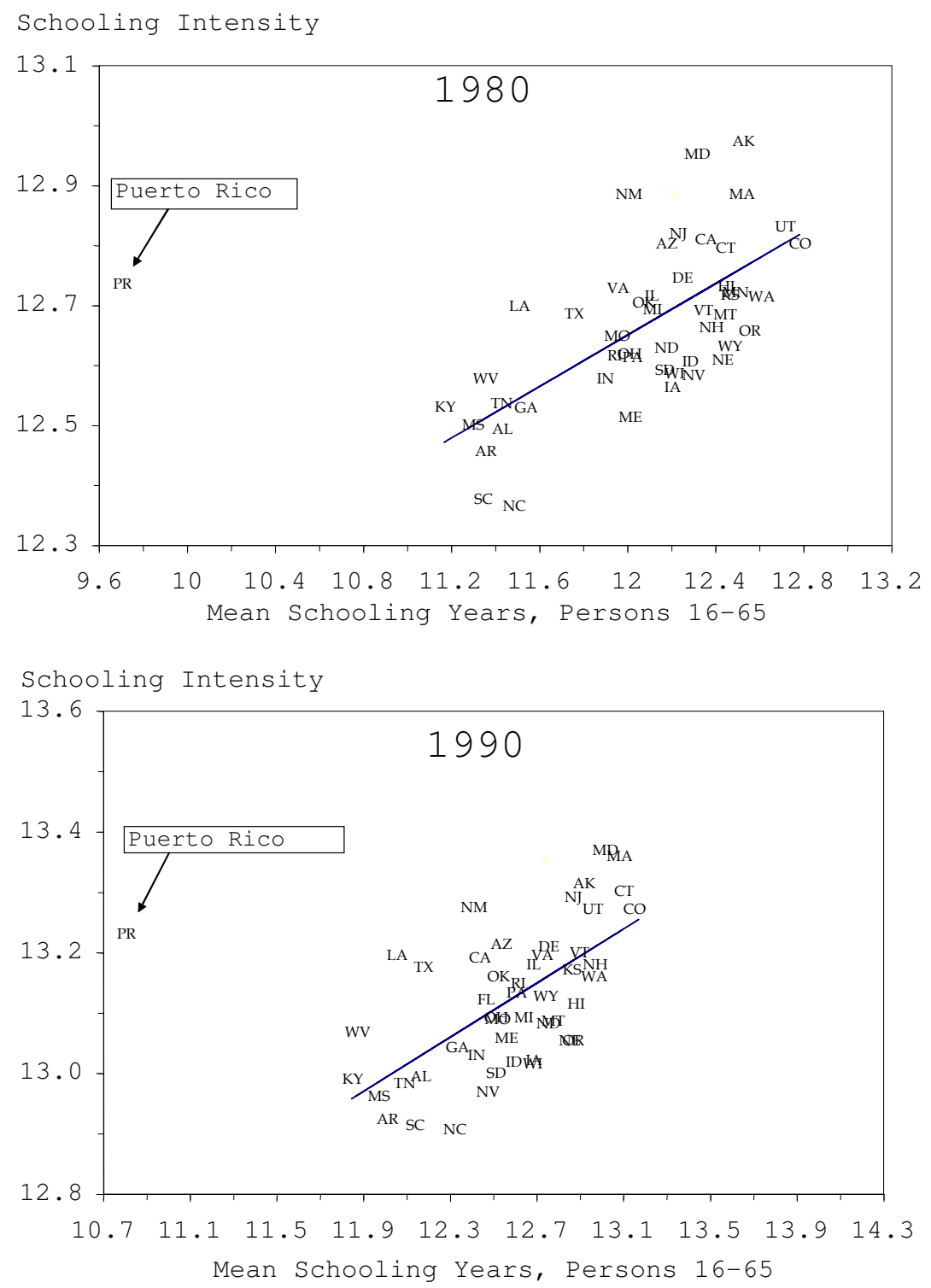

Schooling Intensity

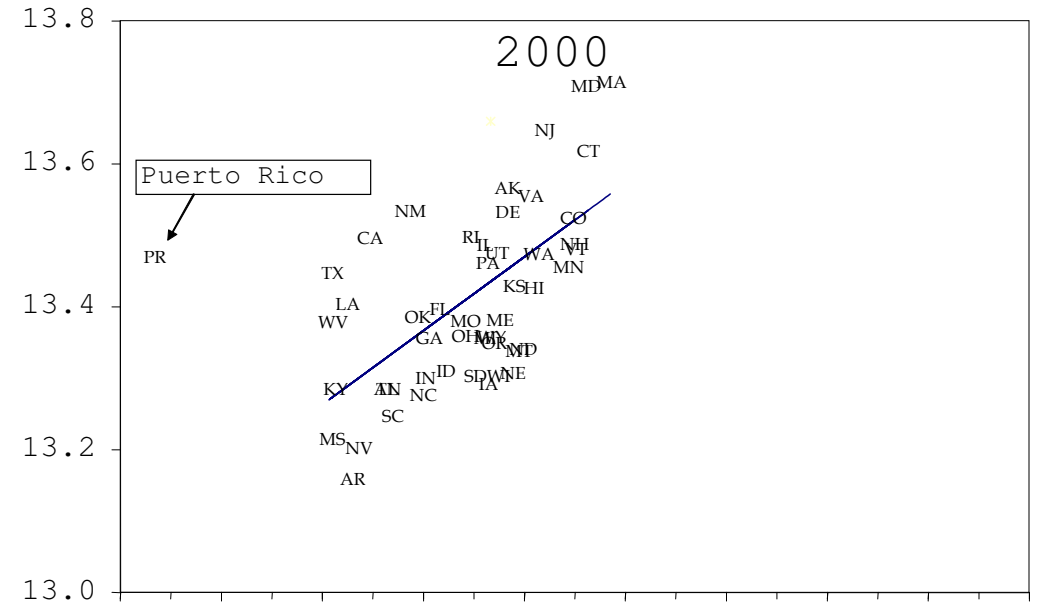

$\begin{array}{llllllllllll}11.5 & 11.9 & 12.3 & 12.7 & 13.1 & 13.5 & 13.9 & 14.3 & 14.7 & 15.1\end{array}$ Mean Schooling Years, Persons 16-65 
Figure 3 Schooling Intensity of State's Industry Mix Versus Mean Schooling Years of Its Workers

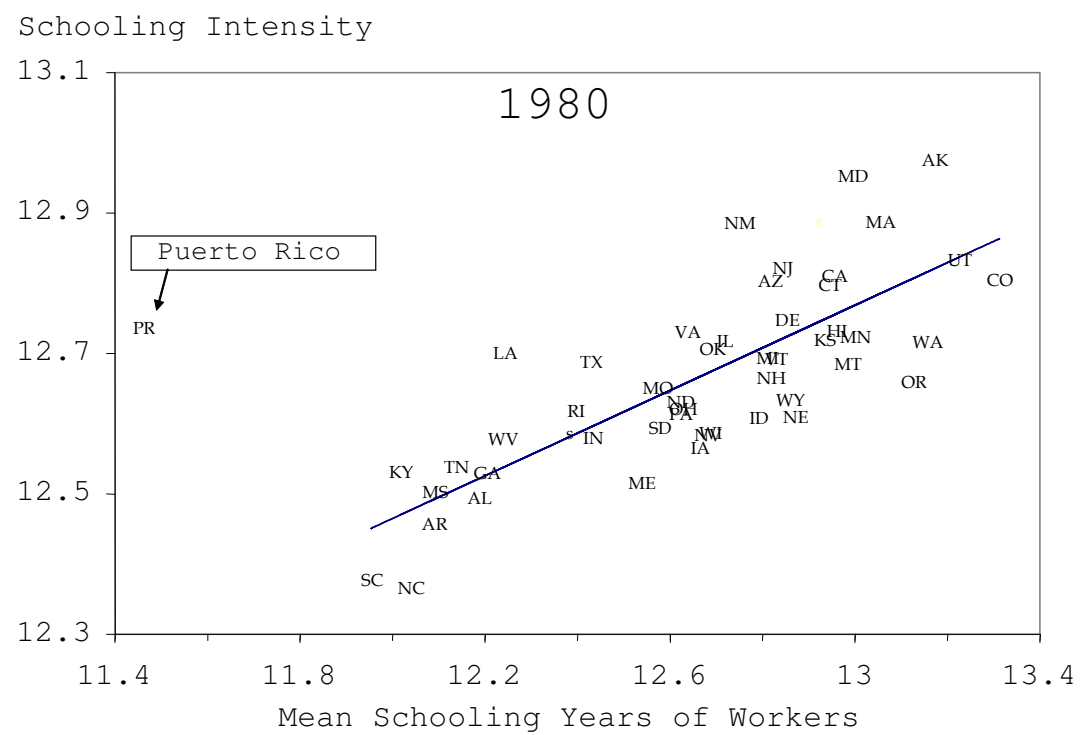

Schooling Intensity

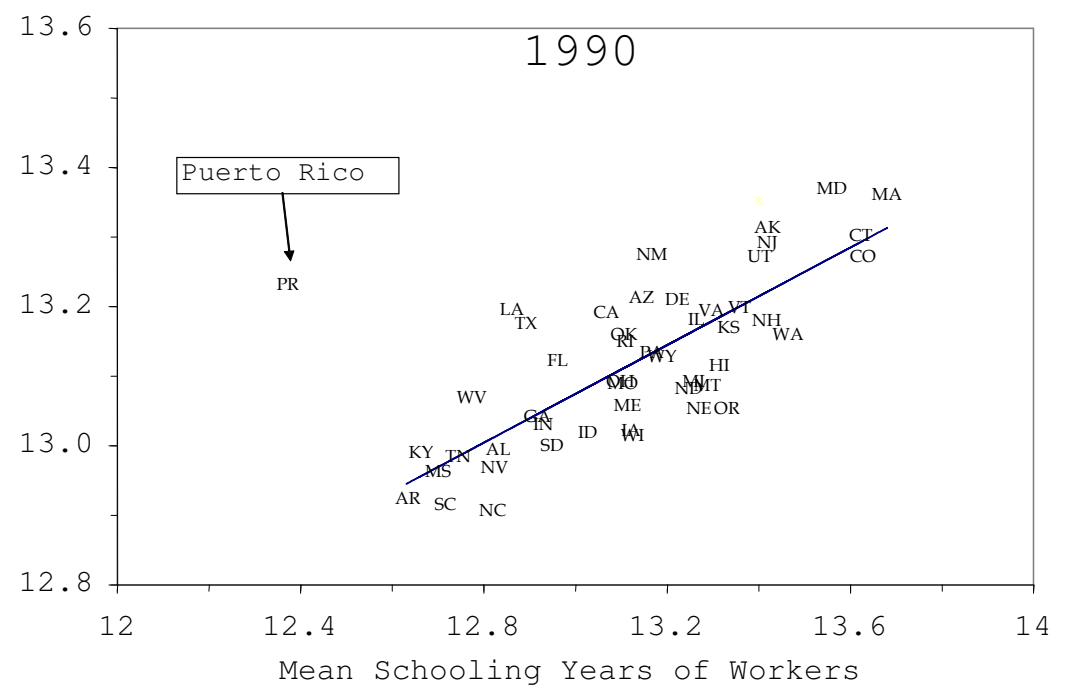

Schooling Intensity

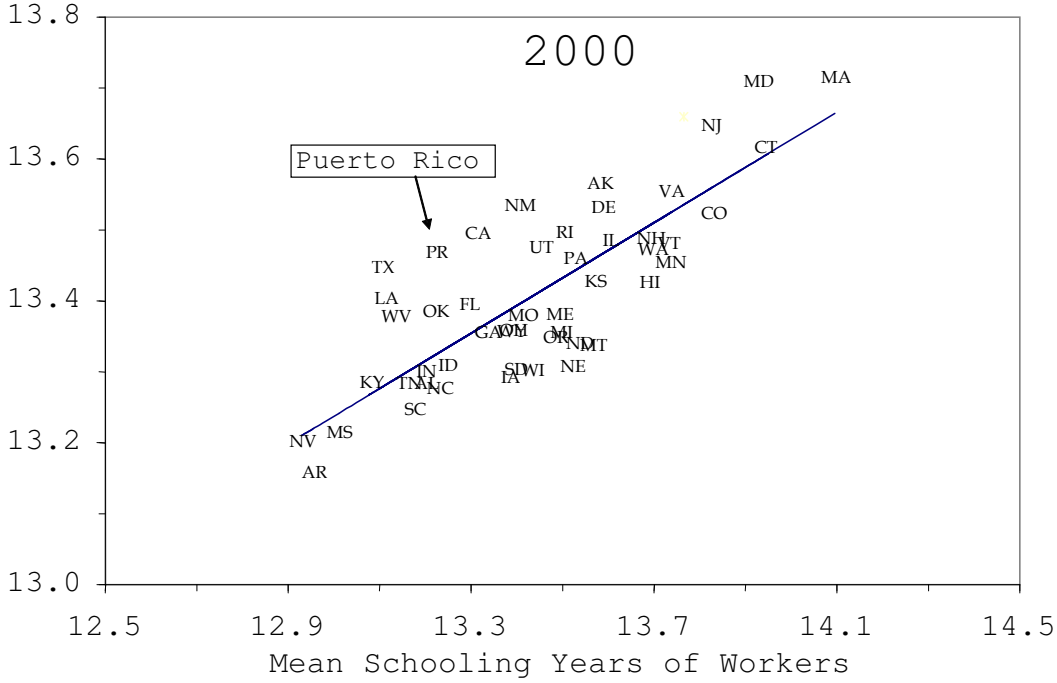


Figure 4: Bird's Eye View of the Permitting Process for Construction and Real Estate Development Projects in Puerto Rico

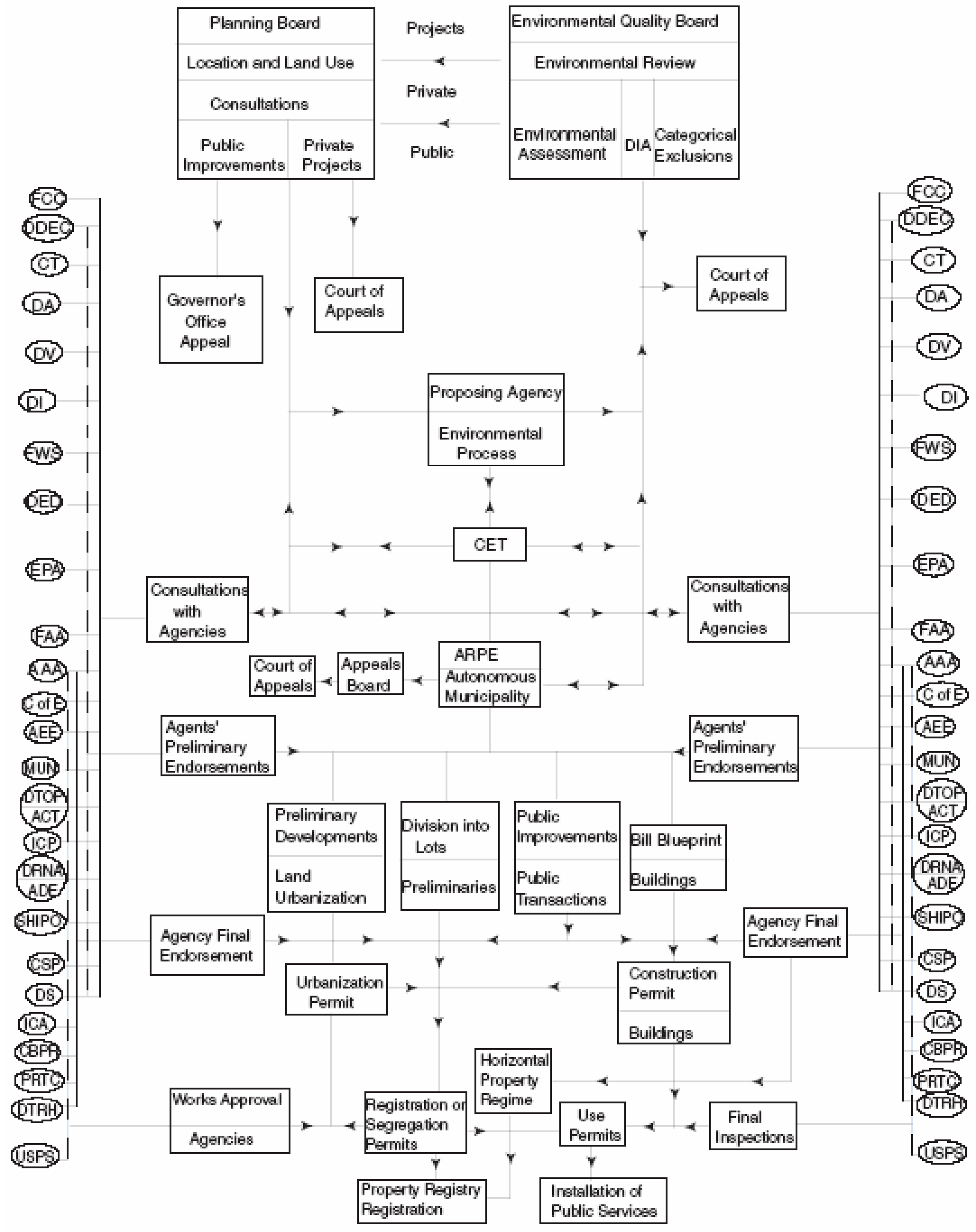




\section{Notes to Figures:}

Figure 1: The charts show employment as a percentage of the civilian population for persons who are 16 years and older. Data for the Puerto Rican chart were supplied by Orlando Sotomayor and derive from two sources: Serie Histórica de Empleo, Desempleo y Grupo Trabajador, 1947-1970, Negociado de Estadisticas, Departamento de Trabajo y Recursos Humanos, Puerto Rico, 1978; and Serie Histórica de Empleo, Desempleo y Grupo Trabajador, 1970-2001, Negociado de Estadisticas, Departamento de Trabajo y Recursos Humanos, Puerto Rico, 2003. Data for the U.S. chart are annual averages of monthly values in the Current Population Survey, as tabulated by the U.S. Bureau of Labor Statistics.

Figure 2: Mean schooling years of persons is calculated as the simple mean years of completed schooling among residents who are 16-65 years old. For education codes not specified in terms of years of schooling, we assigned approximate values. For example, "associate degree" in 1990 and 2000 becomes 14 years of schooling. The schooling intensity of the state's industry employment mix is an index constructed in two steps. First, compute the schooling intensity of each Census industry as the hours-weighted mean years of completed schooling among all U.S. workers in the industry. Industry affiliation reflects the worker's current primary job, defined as the one that generates the largest earnings. The hours worked measure pertains to the reference week in the 1980 and 1990 Census and to usual hours worked per week during the previous calendar year in the 2000 Census. Second, compute the schooling intensity index for the state or commonwealth industry distribution as the employment-weighted mean of the industrylevel schooling intensity values. By construction, an industry has the same schooling intensity in all states and in Puerto Rico. The index quantifies the extent to which a state's industry mix tilts toward schooling-intensive industries, as measured by the industry workforce in the United States.

Figure 3: Mean schooling years of workers is calculated as the simple mean years of completed schooling among employed persons who are 16-65 years old. In other respects, the calculations follow those used in Figure 2. Note that the range of the horizontal axes is 2.0 years in Figure 3, as compared to 3.6 years in Figure 2.

Figure 4: As prepared by Ricardo Solá (2004), an experienced Puerto Rican construction engineer. Acronyms in the diagram are defined below. 


\section{Acronyms in Figure 4}

DIA: Declaración de Impacto Ambiental, Environmental Impact Statement

CET: Centro Expreso de Trámites, Express Center for Procedures

ARPE: Administración de Reglamentos y Permisos, Regulations and Permits

Administration

FCC: Federal Communications Commission

DDEC: Departamento de Desarrollo Económico y Comercio, Department of Economic

Development and Commerce

CT: Compañía de Turismo, Tourism Company

DA: Department of Agriculture

DV: Departamento de la Vivienda, Department of Housing

DE: Departamento de Educación, Department of Education

FWS: US Fish and Wildlife Service

DRD: Departamento de Recreación y Deportes, Department of Recreation and Sports

EPA: Environmental Protection Agency

FAA: Federal Aviation Administration

AAA: Autoridad de Acueductos y Alcantarillados, Aqueduct and Sewage Authority

$\mathrm{C}$ of E: Corps of Engineers

AEE: Autoridad de Energía Eléctrica, Electric Power Authority

MUN: municipality

DTOP: Departamento de Transportación y Obras Públicas, Department of Transportation and Public Works

ACT: ACT: Autoridad de Carreteras y Transportación, Highways and Transportation

Authority)

ICP: Instituto de Cultura Puertorriqueña, Institute of Puerto Rican Culture

DRNA: Departamento de Recursos Naturales y Ambientales, Department of Natural and Environmental Resources

ADS: Autoridad de Desperdicios Sólidos, Solid Waste Authority

SHIPO: State Historic Preservation Office

CSP: Comisión de Servicio Público, Public Service Commission

DS: Departamento d Salud, Health Department

JCA: Junta de Calidad Ambiental, Environmental Quality Board

CBPR: Cuerpo de Bomberos de Puerto Rico, Fire Corps of Puerto Rico

PRTC: Puerto Rico Telephone Company

DTRH: Departamento del Trabajo y Recursos Humanos, Department of Labor and

Human Resources

USPS: United States Postal Service 